San Jose State University

SJSU ScholarWorks

Master's Theses

Master's Theses and Graduate Research

1995

\title{
Distribution and abundance of stream insects as a measure of water quality in a northern California stream
}

Douglas Paul Herman

San Jose State University

Follow this and additional works at: https://scholarworks.sjsu.edu/etd_theses

\section{Recommended Citation}

Herman, Douglas Paul, "Distribution and abundance of stream insects as a measure of water quality in a northern California stream" (1995). Master's Theses. 998.

DOI: https://doi.org/10.31979/etd.338c-fcpg

https://scholarworks.sjsu.edu/etd_theses/998

This Thesis is brought to you for free and open access by the Master's Theses and Graduate Research at SJSU ScholarWorks. It has been accepted for inclusion in Master's Theses by an authorized administrator of SJSU ScholarWorks. For more information, please contact scholarworks@sjsu.edu. 


\section{INFORMATION TO USERS}

This mamuscript has been reproduced from the microfilm master. UMI films the text directly from the original or copy submitted. Thus, some thesis and dissertation copies are in typewriter face, while others may be from any type of computer printer.

The quality of this reproduction is dependent upon the quality of the copy submitted. Broken or indistinct print, colored or poor quality illustrations and photographs, print bleedthrough, substandard margins, and improper alignment can adversely affect reproduction.

In the unlikely event that the author did not send UMI a complete manuscript and there are missing pages, these will be noted. Also, if unauthorized copyright material had to be removed, a note will indicate the deletion.

Oversize materials (e.g., maps, drawings, charts) are reproduced by sectioning the original, beginning at the upper left-kand corner and contimuing from left to right in equal sections with small overiaps. Each original is also photographed in one exposure and is included in rectuced form at the back of the book.

Photographs inchded in the original mamuscript have been reproduced xerographically in this copy. Higher quality $6^{n} \times 9^{n}$ black and white photographic prints are available for any photographs or illustrations appearing in this copy for an additional charge. Contact UMI directly to order.

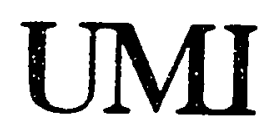

A Bell \& Howell information Company 



\title{
DISTRIBUTION AND ABUNDANCE OF STREAM INSECTS
}

\section{AS A MEASURE OF WATER QUALITY IN}

\section{A NORTHERN CALIFORNIA STREAM}

\author{
A Thesis \\ Presented to \\ San Jose State University \\ In Partial Fulfillment \\ of the Requirements for the Degree \\ Masters of Science
}

The Faculty of the Department of Geography and Environmental Studies

by

Douglas Paul Herman

May 1995 
OMI Number: 1374589

OMI Microform 1374589

Copyright 1995, by UMI Company. All rights reserved.

This microform edition is protected against unauthorized copying under Title 17, Dnited States Code.

\section{UMI}

300 North Zeeb Road

Ann Arbor, MI 48103 
(C) 1995

Douglas Paul Herman

ALL RIGHTS RESERVED 
APPROVED FOR THE DEPARTMENT OF GEOGRAPHY AND ENVIRONMENTAL STUDIES

hempe Tueteo Dr. Lynne Trulio, Assistant Professor of Environmental Studies, Committee Chairperson?

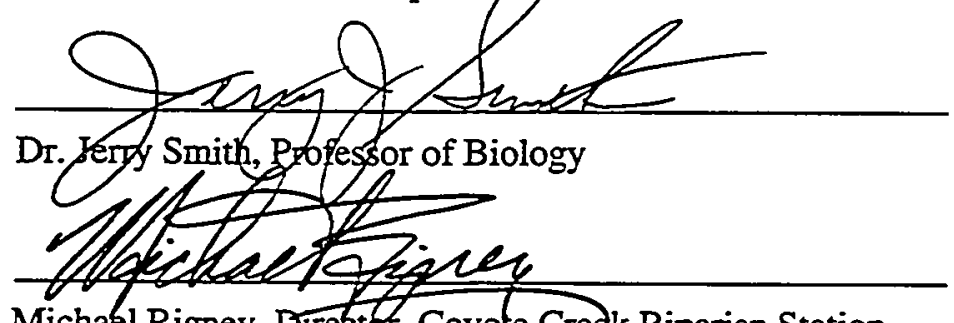

Michall Rigney, Direttor, Coyole Creek Riparian Station

APPROVED FOR THE UNIVERSITY

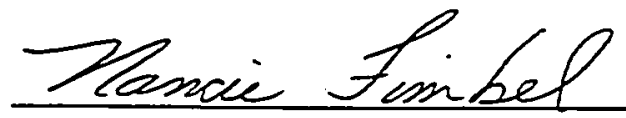




\title{
ABSTRACT \\ DISTRIBUTION AND ABUNDANCE OF AQUATIC INSECTS AS A MEASURE OF WATER QUALITY IN A NORTHERN CALIFORNIA STREAM
}

\author{
by Douglas P. Herman
}

This thesis examines the relationship between the macroinvertebrate fauna present in San Francisquito Creek and land use adjacent to the stream. Water quality parameters including dissolved oxygen, $\mathrm{pH}$, turbidity, conductivity, nitrate, ammonia and phosphate were tested from 4 April 1994 to 13 June 1994 and weekly stream temperature readings, water depth and discharge were determined from 13 May 1993 to 2 October 1993 and 30 March 1994 to 20 June 1994 to understand what impacts these abiotic factors have on the insect fauna. In this study, artificial substrates were used to gather data on aquatic insects. This method was analyzed to determine its potential for use by volunteers performing similar studies in streams of Santa Clara County.

Results showed that macroinvertebrates in San Francisquito Creek are impacted significantly by fluctuations in discharge and increases in stream temperature. Sensitive aquatic insects in the Orders Ephemeroptera, Plecoptera, and Trichoptera were most abundant at upstream stations and pollution tolerant insects in the Order Diptera were most abundant at downstream stations. Water diversion from the stream limits the ability of the creek to rid itself of pollutants and sediment, and low stream flow limits habitat and food availability for the invertebrates. 


\section{ACKNOWLEDGMENTS}

The author wishes to thank all those who helped him complete this study with special thanks to the following. The College of Social Sciences provided a $\$ 1,500$ grant for water quality testing, which proved to be invaluable in assessing the stream. Michael Rigney provided the guidance that $I$ needed by suggesting a macroinvertebrate study to assess the habitat quality of San Francisquito Creek, and also funded a portion of the project. Dr. Jerry Smith warned me about the problems of such a study, but supported me through many of the difficult portions and increased my understanding of aquatic ecosystems. Dr. Lynn Trulio provided many hours of editing, proofreading, consultation, and encouragement, the completion of this thesis would have been much more difficult without her. Kyle Krajewski was a true friend by unselfishly providing many hours of assistance in editing and printing the many drafts of this report. Catherine Herman was always there when I needed someone to talk with and helped me keep everything in perspective. She also taught me one of the most important things in life, never give up on your dreams. 


\section{TABLE OF CONTENTS}

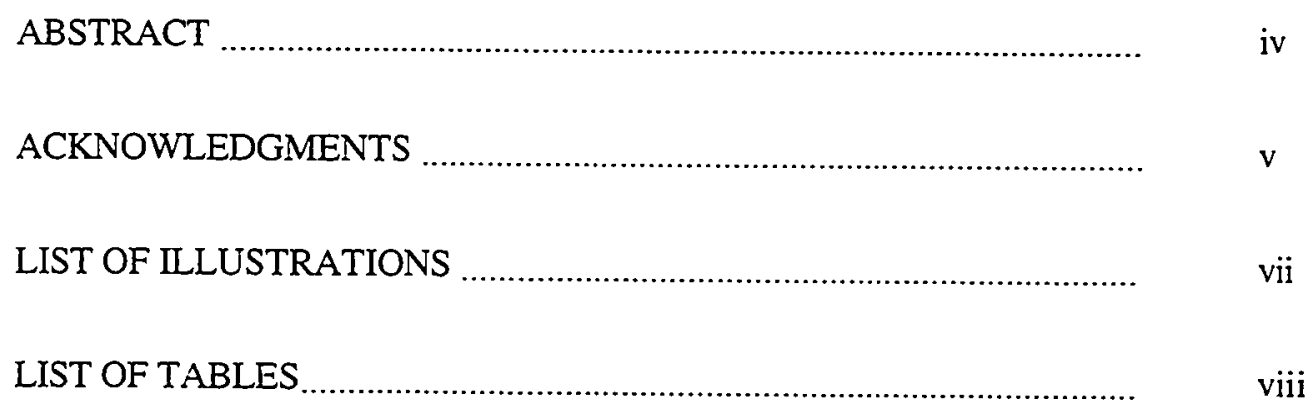

\section{Chapter}

1. INTRODUCTION

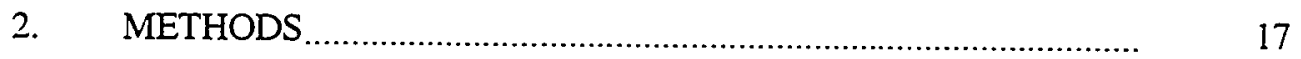

3. RESULTS OF WEEKLY TESTING .......................................... 21

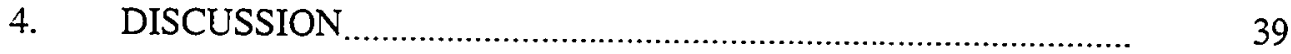

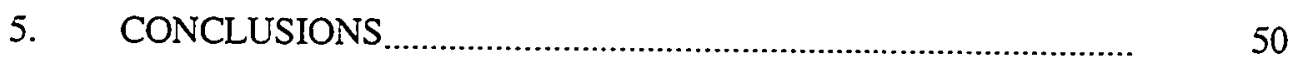

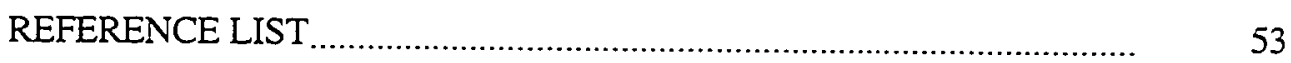

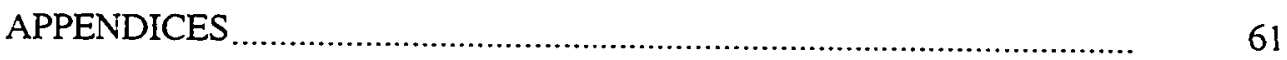




\section{LIST OF ILLUSTRATIONS}

Figure

Page

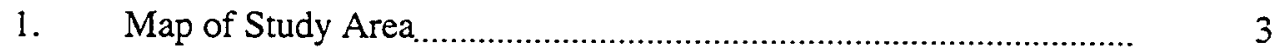

2. Discharge in San Francisquito Creek, 13 June-2 October and Collection Dates ( $\rightarrow$ ) 24 July (Stations 1-6), 7 August (Station 7), 20 August (Station 1), 4 September (Station 2-6), and 2 October (Station 8), 1993

3. Discharge in San Francisquito Creek, 30 March-12 June, and Collection Dates, 12 May and 20 June 1994.

4. Family Richness of Stream Insects at Stations 1-8 in San Francisquito Creek, in Early Summer 1993: 13 June-24 July (Stations 1-6), 30 June-7 August (Station 7); and Late Summer 1993: 24 July-4 September (Stations 1-6), 29 August-

2 October (Station 8); and Total Family Richness in 1993 ...

5. Family Richness of Stream Insects at Stations 1-8 in San Francisquito Creek, in Early Spring 1994: 30 March-12 May

(Stations 1-8) and Late Spring 1994: 12 May-20 June

(Stations 1-8), and Total Family Richness in 1994.

6. EPT/Chironomid Abundance in Early Summer 1993 at Stations

1-6, 13 June-24 July, Station 7, 30 June-7 August.

7. EPT/Chironomid Abundance in Late Summer 1993 at Stations 1-6, 24 July-4 September, Station 8, 29 August-2 October.. 


\section{LIST OF TABLES}

Table

Page

1. Abbreviated Site Characteristics for Stations 1 through 5 and 7 and 8 on San Francisquito Creek and Station 6 on Los Trancos Creek for May 1993.

2. Monthly Range, Mean ( $+/-S D$ ) and Number of Measurements ( $\mathrm{n}$ ) for Stream Discharge in San Francisquito Creek and Rainfall Within the Watershed, October-September 1980-1994.

3. Range, Mean, (+/-SD) and Number of Measurements (n) for Dissolved Oxygen and Water Temperature at Stations $1-8$ in 1993 and 1994

4. Range, Mean, (+/-) SD and Number of Measurements (n) for $\mathrm{NO}_{3}, \mathrm{NH}_{3}, \mathrm{PO}_{4}$ at Stations 1-8, 4 April-13 June 1994....

5. Total Number of Insects collected, Number of Samples, in Early Summer (E) 1993, 13 June-24 July (Stations 1-6) 30 June7 August (Station 7) and Late Summer (L) 1993, 24 July4 September (Stations 1-6), 29 August-2 October (Station 8) (Hilsenhoff Rating [1988a] in Parenthesis Following Insect Family)

6. Family Richness, by Order, for San Francisquito Creek, June-October 1993

7. Total Number of Insects collected, Number of Samples, in Early Spring (E) 1994, 30 March-12 May (Stations 1-8) and Late Spring (L) 1994, 12 May-20 June (Stations 1-8) (Hilsenhoff [1988a] Rating in Parenthesis Following Insect Family)....

8. Family Richness, by Order, for San Francisquito Creek, April-June 1994 


\section{CHAPTER 1 INTRODUCTION}

San Francisquito Creek originates on the east side of the Santa Cruz mountains in San Mateo County, California and flows easterly into San Francisco Bay (Latitude 370 25' $24^{\prime \prime}$, Longitude $122^{0} 11^{\prime} 18^{\prime \prime}$ ) (Figure 1). San Francisquito Creek is first, second and third order in nature with Searsville Dam located near its source. During the winter the majority of stream flow is contributed by Bear Creek, which joins San Francisquito Creek immediately downstream of Searsville Lake. San Francisquito Creek also receives water from Corte Madera Creek watershed. This water overflows Searsville Dam at Searsville Lake. This lake has a capacity of $1.3 \times 10^{6} \mathrm{~m}^{3}$ (952 ac-ft) and was constructed in 1902. Los Trancos Creek, a major tributary to San Francisquito, is located $6.4 \mathrm{~km}$ downstream from Searsville Dam. About $1.1 \times 10^{5} \mathrm{~m}^{3}(800 \mathrm{ac}-\mathrm{ft})$ of water is diverted from Los Trancos Creek each year through the Los Trancos and Lagunita canals for irrigation on Stanford University Campus. San Francisquito Creek drains a watershed of approximately 11,140 hectares (43 square miles). Additionally, 15 smaller creeks, storm water flows and nonpoint source discharges are added to the creek from adjacent oak woodlands, horse pastures, golf courses and suburban areas of Menlo Park and Palo Alto. Los Trancos Creek contributes significant flow to San Francisquito during the summer months when Bear Creek is dry. This stream originates in deep, shaded canyons with private residences, pastures, oak woodlands, and open space grasslands. The two creeks merge south of Interstate 280, and San Francisquito continues through urban and suburban areas, the Stanford University campus, Palo Alto, Menlo Park, and East Palo Alto, and finally discharges into San Francisco Bay, south of Dumbarton Bridge.

Five questions have guided the design of this study: 1) What impacts does land use, such as cattle grazing, agriculture, golf courses and urban areas, have on San Francisquito Creek? 2) What is the characteristic benthic macroinvertebrate fauna of the stream above and below land use runoff into the stream? 3) What is the water quality at these sites and how does it relate to the invertebrate fauna present? 4) Does flow variation between years affect diversity and abundance? 5) And finally, can the methods employed 
in this study to assess the habitat of the stream be used by a non-professional on other streams in northern California?

Flowing next to Stanford University in its downstream reaches, San Francisquito Creek has been the topic of several student reports (Sokol 1963; Ancher 1976; Duff 1987; Stanford 1989). These reports were based primarily on hydrologic and flood control issues. San Francisquito Creek overflowed its banks on December 22, 1955, resulting in two million dollars in damages and the flooding of 700 homes.

The degradation of this creek and others has led to substantial public interest in Santa Clara County creek water quality. Given this interest, Mike Rigney of the Coyote Creek Riparian Station (CCRS) has initiated a county-wide study of the current conditions of, and restoration opportunities for, Santa Clara County creeks. CCRS wants to develop an ongoing volunteer creek monitoring program. California is only one of four states without such a program (Rigney 1993, 1).

The research described in this thesis was undertaken to assist CCRS in assessing creek water quality and developing the monitoring program. Aquatic insects were chosen as the indicator of stream quality and artificial substrates were chosen as the method of data collection to determine if they could be adapted to a citizens monitoring program. 


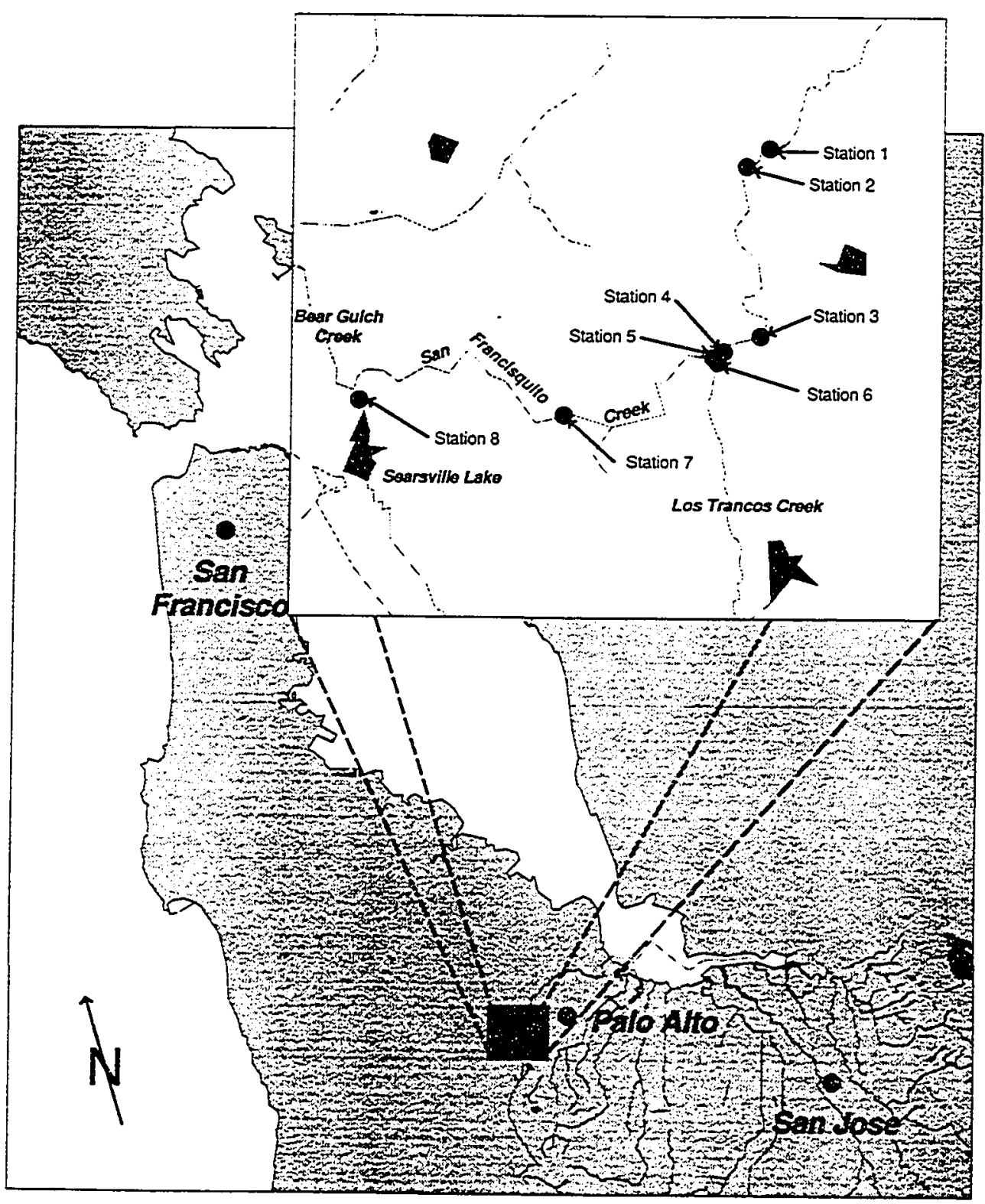

Fig. 1. Map of San Francisquito Creek. 


\section{Background}

The primary focus of this study is an analysis of the stream insect population along a reach of San Francisquito Creek to determine: 1) the relative abundance and distribution of benthic insects in the stream;2) the richness of benthic insects in the stream to the family level; 3) the relative healthiness of the system at each sampling site and in the stream in general based on the presence of pollution-sensitive forms of macroinvertebrates. Other work on this subject suggests that the abundance and richness of macro-invertebrates will decrease as water quality decreases in otherwise good stream habitat (Brinkhurst 1965; Hawkes and Davies 1970). A large body of literature suggests that aquatic macroinvertebrates are excellent indicators of water quality (Lenat 1988; E.P.A. 1989; Eaton and Lenat 1991). These species are very appropriate to use when assessing and monitoring human-caused impacts on stream environments.

Biosurveys of the habitat can be implemented once an understanding of the processes involved in stream ecology and the role of aquatic insects in these systems is attained. Biosurveys may be used within a planning and management framework to prioritize water quality problems for more stringent assessment and to document "environmental recovery" following control action (EPA 1989).

In 1989 the Environmental Protection Agency produced an excellent document on the feasibility of using benthic macro-invertebrates to assess water quality in streams. Cairns and Dickson (1971) note the advantages of using benthic macroinvertebrates for biomonitoring:

1) Macroinvertebrate communities are good indicators of localized conditions because many benthic macroinvertebrates have limited migration patterns or a sessile mode of life, they are particularly well suited for assessing site-specific impacts (upstream-downstream studies).

2) Macroinvertebrate communities integrate the effects of short term environmental variations. Most species have a complex life cycle of approximately 1 year or more. Sensitive life stages will respond quickly to stress; the overall community will respond more slowly.

3) Degradation can often be detected by an experienced biologist with only a cursory examination of the macroinvertebrate community.

Macroinvertebrates are relatively easy to identify to family and many

"intolerant" taxa can be identified to lower taxonomic levels with ease. 
4) Sampling is relatively easy, requires few people and inexpensive gear and has no significant effect on the resident biota.

5) Benthic macroinvertebrates serve as a primary food source for many recreationally and commercially important fish.

6) Benthic macroinvertebrates are abundant in most streams. Many small streams (1st and 2nd order), which naturally support a diverse macroinvertebrate fauna, only support a limited fish fauna.

7) Most state water quality agencies routinely collect macro-invertebrates and have background macroinvertebrate data. Most state water quality agencies have more expertise in aquatic entomology than in ichthyology.

\section{Stream Ecosystems}

An understanding of natural stream habitats is integral to assessing impacts to aquatic invertebrates. Cummins (1974) gives a detailed examination of stream habitats and the function of stream insects within the system. Emphasis is on the manner in which stream insects utilize organic matter.

Organic material entering streams as particles (particulate organic matter or POM) and in solution (dissolved organic matter or DOM), and similar materials produced in the stream itself, are processed to carbon dioxide and nutrients. A certain amount is absorbed by resident biological components and the remainder is exported downstream.

After the introduction of course particulate matter (CPOM, generally greater than $1 \mathrm{~mm}$ in diameter), such as leaves, needles, twigs, and bark into the stream, two processes occur rapidly. Soluble organic matter extracted from the CPOM enters the DOM pool, and CPOM surfaces are colonized by microorganisms and spores of bacteria, fungi, and protozoans. The leached, microbially colonized CPOM is broken down to fine particulate organic matter (FPOM) and very fine particulate organic matter (VFPOM) by the turbulent conditions in the lotic environment and by two natural and complimentary community processes, animal feeding and microbial metabolism.

Stream macroconsumers play an important role in the conversion of particle sizes. They are generally considered to be those animals, dominated by invertebrates, that attain a size of at least $3 \mathrm{~mm}$ to $5 \mathrm{~mm}$ at termination of growth. The primary role of these stream invertebrates is conversion and reduction of detritus in the stream. Therefore, the functional groups of stream insects are recognized on the basis of particle size fractions 
eaten and the method of feeding. Predators are recognized as converters of particles and as controllers of the non-predator insect populations in the stream.

Cummins (1974) offers stream management strategies on the basis of functional groups and the amount and size of organic matter in the stream. He concludes that the maintenance of water quality is based on the relationship between CPOM, FPOM, and DOM together with the involvement of critical functional groups of micro and macroorganisms. For a well-functioning stream, about one-third of the total detritus and other organic matter should be converted to $\mathrm{CO}_{2}$ annually and in-stream plant growth the fuel to drive the system. If these processes are impaired, stream water quality is likely to be reduced.

Cummins' (1974) theory on stream ecosystems is based on a number of generalizations that have been tested primarily on wooded streams of the temperate zone (Teal 1957; Hynes 1961; 1970; Nelson and Scott 1962; Egglishaw 1964; Minshall 1967: Tilly 1968; Hall 1972; Fisher and Likens 1973). Minshall et al. (1978) reports that this emphasis on forest biomes has overshadowed the importance of autochtonous (within) production of streams, especially in desert and semi-desert regions. He tested his theory on Deep Creek (Minshall et. al., 1972, 1973, 1975, 1978) a small stream located in southern Idaho. The streamside vegetation consists primarily of sagebrush (Artimesia tridentata) and grasses. Minshall examined the energy budgets at several sites along Deep Creek and concluded that allochthonous (outside) inputs were minor and that in-stream production of organic matter sustained the system.

When comparing streams from different biomes, the deciduous and coniferous forest regions obtain the majority of their energy from outside the stream and in drier climates the majority of the production is in-stream. However, because light plays an important role in determining autotrophy and heterotrophy in streams, several investigators (Cummins 1974; Fisher and Likens 1973; Vannote 1977) have suggested that small headwater streams will be heterotrophic, because of shading, and larger rivers will be autotrophic. In heavily forested regions this seems to be true, but in the arid and semi-arid portions of the western United States the effects of shading tend to be negligible. Many of the streams receive substantial amounts of organic inputs from the watershed but, in many cases because of reduced or intermittent flows, streamside vegetation is reduced and autotrophic sources predominate on an annual basis. It can be concluded that in the larger streams of forested regions and streams of all sizes in major portions of the arid and semi- 
arid west, in-stream production of organic matter plays the major role in their trophic economy.

Anderson and Cummins (1979) discuss the functional feeding groups of benthic organisms based on food-acquiring mechanisms. The range of organic matter potentially available as food for aquatic insects extends from the highly refractory to the readily digestible. The relative nutritional gradient from poor to good is: (1) wood; (2) terrestrial leaf litter; (3) fine particulate organic matter; 4) decomposing vascular hydrophytes and filamentous algae; (5) living algae, especially diatoms; and (6) animal tissues.

Considerable evidence has accumulated that food categories 1-4 are the primary sources of nutrition for aquatic invertebrates (Barlocher and Kendrick 1973a).

The functional groups of stream insects and their food acquiring mechanisms are as follows:

\section{(1) Gougers and Shredders}

This functional group includes those species that feed on CPOM (food categories 1 and 2) and reduce the particle size by gouging and mining wood and consuming leaf litter.

\section{(2) Collectors}

In contrast to shredders, collectors utilize FPOM that is primarily surface colonized by bacteria.

\section{(3) Scrapers}

Scrapers are dependent on in-stream production of algae as a food source but their mode of feeding also results in ingestion of detritus as well as organic layers on stones.

\section{(4) Predators}

Predators tend to have high digestion efficiencies of $75 \%$ to $85 \%$ (Heiman and Knight 1975). Although food quality is high, the quantity can vary significantly. Thus, effects of food on the life cycles of predators depends on density of prey, numbers or biomass of predators, or differences in larval development of the predators and the insects on which they feed.

Vannote et al. (1980) and Cummins (1975) developed the River Continuum hypothesis which suggests that, along with food production outside and within the stream 
channel, other factors such as stream morphology, current velocity, substrate composition, and temperature play a major role in food availability to invertebrate consumers. These parameters will vary from headwater streams to larger rivers and thereby regulate distribution patterns of invertebrate functional feeding groups.

When species density-food relationships are examined along with patterns of distribution, the River Continuum hypothesis of functional feeding group presence becomes more meaningful. The abundance of food resources available will directly affect the aquatic invertebrate composition of the stream. 


\section{Water Quality Assessment Using A Biotic Index}

A "saprobic index" (Pantle and Buck 1955) and a "biotic index" (Chutter 1972) were proposed for evaluating the water quality of streams through the study of their fauna. Hilsenhoff (1977) proposed a similar biotic index that used only arthropods for evaluation, thus simplifying collecting, sorting, and identification. It was based on a sample of 100 or more invertebrates collected from a riffle area. This index is a measure of organic and nutrient pollution, which causes lower dissolved oxygen levels, especially at night during the summer and after heavy rain. Lower dissolved oxygen in turn differentially affects the ability of each species of arthropod to survive in a particular stream.

Initial tolerance scores for each species were based mostly on a study of 53 Wisconsin streams in which physical and chemical parameters were evaluated to determine the degree of organic and nutrient pollution in each stream (Hilsenhoff 1977). The family level of identification and associated tolerance scores were developed by Hilsenhoff (1988a) to reduce the time involved in identification and, therefore, the cost of such studies. The tolerance values for families of stream arthropods in the Western Great Lakes Region are listed in Appendix A. The orders of Ephemeroptera, Plecoptera, and Trichoptera (EPT) generally have families with low tolerance scores and families in the Order Diptera generally have high tolerances, though some exceptions occur.

\section{Stream Flow Effects}

The majority of studies involving macroinvertebrates in the United States have been performed on streams in the northern portion of the country. Within the central Pacific Coast Region of North America, however, the local Mediterranean climate produces conditions which result in differences from the temperate areas. Within this region nearly all of the precipitation falls between the months of November and March. The seasonally high rainfall coupled with the steep gradients of many streams in the region can cause what is termed "washout" by Siegfried and Knight (1977). "Washouts" are characterized by high flows, scour, and sediment deposition and rearrangement. These high flows occur during the course of winter and usually result in the catastrophic removal of benthic macroinvertebrates (McElravy 1988). During the dry season, beginning in April, streamflows gradually recede, with many smaller streams becoming intermittent. In the 
summer, many streams in the region are characterized by high temperatures and accumulation of debris and sediment.

Large increases in discharge appear to be the most common cause of catastrophic insect loss (Fisher et al. 1982; Resh et al. 1988a). Even small increases in stream discharge can result in the lowering of insect populations, probably due to increased drift and mortality from movement of substrate (Brooker and Hensworth 1978; Scullion and Sinton 1983; Sager 1986). Insects attached to substrate or between rock crevices are probably more susceptible to sudden increases in discharge than surface dwelling or more mobile taxa (Thorup 1970; Sager 1986). Flash flooding and the associated substrate movement can cause removal of both macrobenthic insect species and algae (Moffett 1936; Sigfried and Knight 1977; Bane and Lind 1978; Fisher et al. 1982; Molles 1985), creating a disturbance of the trophic structure for several months or more (McElhone et al. 1987). A return to pre-flooding conditions after severe flooding may take a year or longer.

Drought is a catastrophic event for aquatic insects because of their need for an aquatic environment with adequate flow and dissolved oxygen levels throughout their life cycle. Aquatic insects and their susceptibility to droughts has been studied over a broad spectrum of conditions ranging from reduced discharge (e.g., Iverson et al. 1978; Pearson 1984), to intermittent flows (e.g., Hynes 1958; Larimore et al. 1959; Kamler and Riedel 1960), to complete loss of aquatic habitat (Resh 1982). If flow is reduced but not to the degree that it becomes dry or intermittent, studies show that densities of some taxa decrease (e.g. current-loving forms, passive filter feeders) while others increase in density (e.g. other filter feeders, detritivores, silt tolerant forms) (Extence 1981; Pearson 1984). If surface flow ceases altogether, high mortality in a number of species is often observed. Those species that can burrow into the bottom sediment, and remain in a dormant stage such as a dispausing egg, or that leave the stream as flying adults can survive through the dry period (Williams and Hynes 1977; Iverson et al. 1978). If the entire stream becomes dry to a significant depth into the substrate, all species are lost except those in resistant egg cases. Recolonization results when ovipositing adults migrate from nearby habitats (Larimore et al. 1959; Resh 1982). This recolonization can be fairly rapid in some instances (<lyr) ( Larimore et al. 1959; Gore 1985).

It is obvious from these studies that invertebrates are additionally stressed in streams that become intermittent or have seasonally high discharges associated with the local climate. San Francisquito Creek can be impacted by both of these variables. Though 
it lacks steep gradients the watershed is large, (43 square miles), and runoff is substantial during the wet season.

\section{Human Impacts Affecting Macroinvertebrate Composition}

Biotic and abiotic factors important to stream macroinvertebrates can be directly affected by land use practices in stream watersheds. Land use around a stream can modify vegetation and consequently the amount and quality of food, by increasing the sediment load and run-off of other pollutants.

The pollutant loadings from non-point sources can be significant (Wanielista 1976). When studying a large basin, sources of non-point pollution often include urban areas, silviculture, agriculture, construction, wetlands, waterfowl, and rainfall. Obvious nonpoint source effects on water quality begin with rainfall, which can vary in purity from one area to the next. Rainwater contributes chemical substances to waters and should, therefore, be considered when studying the impacts to a particular water-body. Overall, land use impacts on water quality and can be broken down to two categories: rural and urban.

Rural non-point sources. Rural sources can contribute significant amounts of water pollutants. Agriculture is a source of fertilizers, pesticides and other agricultural chemicals. A study performed by Wallace and Dague (1973) showed that the dissolved oxygen content of Iowa rivers was linked directly to agricultural sources. Animal feed lots, orchards, and groves all contributed to the problem of non-point water pollution. Generally, the greater the amount of human utilization or animal density, the greater the amounts of pollutants introduced and the lower the dissolved oxygen. The extent of the pollutant impacts will depend on climate and landscape factors in addition to the quantity of water for dilution.

Urban non-point sources. Urban runoff contains many pollutants from widely varying sources, ranging from birds to vehicle tires to construction activities. The water chemistry of urban runoff has been extensively studied, and a variety of contaminants including nitrogen, pesticides, lead and other heavy metals, oil, salt, chromates, cyanide, organic materials, and suspended and dissolved solids have been reported (Weibel et al. 1966; Field 1975; Wanielista et al. 1977). Inorganic materials in dirt and dust contribute the major portion of urban runoff contaminants. 
The volume and type of traffic moving over streets has an effect on the contaminants present. More contaminants will be present on crowded city streets than on rural roads. The physical condition of the street surface is also important. Roads in poor condition usually have higher loadings than good street surfaces. The time of year is also a factor. Heavy rainfall incidents after a dry period will transport large amounts of pollutants to nearby streams. In general, urban effects are higher except in relationship to total nitrogen from cultivated lands.

Clearly, non-point source pollution and its impact on streams can be significant. Although the intermittent nature of runoff from these sources makes detection difficult, studies suggest (Wallace and Dague 1973; Harms et al. 1974; Wanielista 1976) that as urban and agricultural use increases water quality will decrease.

Stream invertebrates can be a valuable tool for indicating poor water quality which routine chemical monitoring may not detect. The following studies are presented to show the relationship between land use, water quality, and macroinvertebrate distribution and abundance.

\section{Macroinvertebrates and Impact Assessment}

Urban runoff has been recognized as an important source of pollution in receiving waters (Wanielista 1976), and is a potential impact along much of San Francisquito Creek, which flows along Alpine Road and under Sandhill Road.

A study by Whiting and Clifford (1983) was undertaken to examine the effects of urban runoff on the invertebrate fauna of Whitemud Creek passing through the city of Edmonton, Alberta, Canada. Seven sampling locations in riffle habitats were selected within the city. The sites were chosen to assess the effects of two storm sewer outlets and general changes along the entire length of stream within the city.

The observed changes in the macroinvertebrate community were almost certainly the result of urban runoff. All sites on the stream had similar substrate, current velocity, and water depths. Also, water temperature varied little along the reach of stream, and no discharges other than storm sewer runoff entered Whitemud Creek within the city. There was a large difference between two stations, which were only $50 \mathrm{~m}$ apart but had a large sewer outlet between them.

The results of the study indicated organic enrichment was the most important factor affecting the invertebrate fauna on Whitemud Creek. The two tubificid species found 
dominating the urban fauna, Tubifex tubifex and Limnodilus hoffmeisteri, are often associated with organic enrichment (Brinkhurst 1965; Whitely 1968; Aston 1973).

Whiting and Clifford (1983) concluded that organic enrichment, rather than toxic substances was the most important factor affecting the invertebrate fauna on Whitemud Creek. The two tubificid species found dominating the urban fauna, Tubifex tubifex and Limnodilus hoffmeisteri, are often associated with organic enrichment (Brinkhurst 1965; Whitely 1968; Aston 1973).

Macroinvertebrates that have been reported to be intolerant of organic pollution decreased in within the city including the Amphipod, Gammarus (Surber 1953; Butcher 1955; Hawkes and Davies 1970; Nuttall and Purves 1974), Ephemeroptera, Heptagenia (Butcher 1955), Trichoptera, Hydropsyche (Butcher 1955; Learner et al. 1971) Diptera, Hexatoma (Paine and Gaufin 1956) and Diptera, Simulidae (Surber 1953).

Water and sediment tests for chloride and chromium showed no correlation with invertebrate species abundance and heavy metals did not seem to be important as many species sensitive to heavy metals were present. The lack of correlation between chemical or physical data and the macroinvertebrate community was probably due to the sporadic nature of urban runoff. Rigorous chemical sampling would be needed to monitor the effects. In contrast, aquatic invertebrates exhibited long-term responses to sporadic runoff incidents and provided a valuable tool for monitoring the effects of urban runoff.

Tiller $(1993,246)$ studied the effects of human disturbance on the Threbo River in Kosciusko National Park, New South Wales, Australia. The river passes by a ski resort, Threbo Village, which discharges treated sewage. Replicate collections of benthic macroinvertebrates were conducted at eight stations and total numbers were used as a biological measure likely to be affected by the sewage outflow.

Sites below the village, and immediately below the sewage outflow, had much larger numbers of pollution tolerant macroinvertebrates than any of the other sites, demonstrating an effect by both the effluent outflow and the village itself.

These studies demonstrate that urban runoff can severely alter aquatic ecosystems. It is also evident that these impacts can be difficult to assess using routine water quality testing. General trends can be assessed, but pollution pulses (e.g. after rainfall or snowmelt) may be missed. The stochastic nature of urban runoff makes a direct correlation of water quality to system health difficult. Efficient water quality monitoring apparatus would have to quickly respond to pollution pulses. It would be expensive and could still not determine potential impacts because of dilution effects during storms. Aquatic insect 
studies are valuable because the invertebrates must assimilate pollutants over a long period of time and the population structure can indicate the overall severity of the impact.

\section{Qualitative vs. Quantitative Methods}

Many macroinvertebrate studies use quantitative methods to assess water quality impairment as compared to a qualitative approach. Quantitative approaches use sampling apparatus such as a Surber sampler, that collect most of the macroinvertebrates in a specified area, depending on the size of the sampling apparatus. Quantitative approaches yield better results statistically than qualitative methods, but are often more costly because of the additional time required for sorting, identification, and the expertise in the collection regime. In recent years a shift toward qualitative studies or "rapid assessment approaches" has occurred (Lenat 1988, Hilsenhoff 1987, EPA 1989, Eaton and Lenat 1991). Data are collected utilizing a coarse meshed kick sampler, Surber sampler, or another variety depending on stream depth and substrate. The purpose of using a rapid bioassessement approach is to identify water quality problems associated with both point and non-point source pollution and to determine long term regional changes in water quality (Resh and Jackson 1993, 195).

The rapid bioassessment approach involves sampling and analysis that is designed to fulfill two objectives. First, effort is reduced in assessing the health of the system as compared to more quantitative approaches. This is achieved in several ways: (1) the number of habitats sampled and replicate sample units taken per habitat are reduced; (2) less silt and debris are collected, which makes sorting easier; (3) only a fraction of the animals collected may be considered, which means fewer have to be identified: or (4) specimens are identified only to family level.

A second purpose of rapid assessment approaches is to summarize the results in a fashion that can be understood by non-specialists such as managers, decision makers, or the general public.

Artificial substrates, the method employed in this study, is a semi-quantitative method. This term is applied because the entire sample is analyzed for a specific area of stream, but the samples may not be fully representative of the benthic community at a station since, artificial substrates often selectively sample certain taxa. Samples also eliminate substrate as a factor in collection results. 
This method was chosen because it is ideal for use by volunteers or other nonprofessionals (Smith 1993). Sampling errors associated with quantitative collection methods are reduced because the samplers are simply placed in the stream in a riffle habitat. Sampling does not involve special expertise, identification of different habitats, or interobserver reliability problems. Because proper taxonomic keys are unavailable at this time for larval forms of aquatic insects of California, they must be identified to the family level (Resh 1994).

Resh and Jackson $(1993,197)$ suggest six invertebrate species parameters to measure community health:

* Measures of richness describe the number of specific taxonomic groups in a sample (e.g. species, families) and is an estimate of community structure.

* Enumeration involves counting all macroinvertebrates collected to estimate relative abundance of different taxonomic groups (i.e., number of individuals in certain orders, families, or species, or numerically dominant taxa in these groupings). Essentially, no taxonomic effort is necessary for total number of individuals; relative abundance requires distinctions based on the group under consideration (e.g., number of individuals for a given family or species).

* Calculation of community diversity combines richness and enumeration as a final measure. Total number of taxa provides a richness component and, the number of individuals per taxon provides an eveness component (Washington 1984).

*Community similarity indices are used to compare community structure among different sites or from year to year. Family or genus level of taxanomic discernment is necessary for their use. Community indices differ with some stressing richness (e.g., Jaccard Index) or both richness and abundance (e.g., Pinkham-Pearson index).

*Biotic indices use water quality tolerance values for taxa (families, genera, or species) that have been collected and identified. An example of this is the Hilsenhoff (1988a) index. Tolerance values range from 0-10 for families and increase as water quality decreases. The index was developed by Hilsenhoff (1977) to summarize various tolerances of the benthic macroinvertebrate community with a single value.

* Functional feeding group measures are based on the mouthpart structure of the invertebrate and its food acquiring method at a given site. Functional groups of macroinvertebrates reflect trophic levels and are based on digestive tract analysis (Cummins 1988). 
To study the reliability of the rapid bioassessment approach, the measures were tested on several northern California coastal streams (Resh and Jackson 1993, 210). The analysis methods were tested for their accuracy and their ability to avoid Type 1 errors (that the impact has occurred when, in fact, it has not occurred) and, the ability to avoid Type 2 errors (the measure does not indicate impact when, in fact, it has occurred).

All richness measures detected significant differences in impacted sites or years. Richness measures were very accurate in avoiding both Type 1 and Type 2 errors.

The family biotic index showed lower similarities $<80 \%$ under impacted conditions than under unimpacted conditions $>90 \%$, and reductions under impacted conditions were statistically significant.

Number of individuals can increase or decrease under impacted conditions, so both possibilities were considered in the enumerations analysis. Percent similarities were highly variable for this measure and overlapped under impacted and unimpacted conditions. They concluded that enumerations are not consistent enough to be used effectively in rapid assessment approaches.

Of the functional measures used, only the ratio of scrapers to total number of individuals (\% scrapers) showed reduced similarity and statistically significant differences when impact occurred.

In summary, the responses of all seven measures (four richness measures. Margalef's Index, the Family Biotic Index, and ratio of scrapers to total number of individuals) to both acid and thermal impacts were accurate and statistically significant. However, seasonal differences were found for almost all of these measures. Thus, comparisons among seasons require caution.

Using multiple measures appears to be preferable to reliance on a single measure for analyzing impacts to streams in northern Califormia. First, richness is an important measure of community structure. Species level taxa richness would be preferred but family level will suffice. Second, a measure weighted for pollution tolerances, such as the Biotic Index with regionally modified tolerance scores, is important. Third, the ratio of scrapers to total individuals would provide a functional measure. However, individuals must be identified to the species or genus level, making it unsuitable for some studies.

As a final consideration, differences were always more evident when two different sites or different seasons at a site were compared than when annual differences observed at a single site were compared. 


\section{CHAPTER 2}

\section{METHODS}

This study of water quality and the characteristic benthic macroinvertebrate population existing on San Francisquito Creek was based on the analysis of: (1) total abundance of macroinvertebrates found at the stream stations and their tolerance score to organic pollution, (2) species richness of macroinvertebrates at each site, (3) water quality measurements and, (4) statistical analysis to determine the relationship of water quality to species richness and abundance.

\section{$\underline{\text { Studv Area }}$}

This study was conducted in San Francisquito Creek, with study sites in those portions of the stream ranging from first to second to third order in nature. The stream flows easterly through San Mateo and Santa Clara Counties to the San Francisco Bay. The watershed has a number of land uses, including urban, agriculture, ranching, recreationgolf course and open space. Nearly all the annual precipitation falls during the 9-month period from September to May. During the wet season storms can increase the flow in San Francisquito Creek from 20 to 100 times the base flow, resulting in significant scour and rearrangement of streambed materials.

Seven stations along a 9500 meter length of San Francisquito creek and one station on Los Trancos Creek (elevation ranges from 21 meters at station 1 to 122 meters at station 8) were established (Figure 1). These stations were chosen to study the effects of various land uses in the watershed and general changes along the stream. Station 8 , the control station, was located in Jasper Ridge, an Ecological Preserve. This station was upstream from all land use and 100 meters downstream from Searsville Lake. Stations 7 and 5 were immediately downstream from Boething Tree Farm and Portolo Valley horse ranch, respectively. Station 6 on Los Trancos, near its confluence with San Francisquito Creek, 
was chosen because it contributes substantial flow to San Francisquito creek and, therefore, has an impact on water and habitat quality of the stream throughout the year. The nonpoint source impacts to Los Trancos Creek are relatively light. Private residences, pastures, oak woodlands, and open space grasslands characterize the watershed. Station 4 was situated 46 meters downstream of site 5 and 45 meters downstream of the confluence of San Francisquito and Los Trancos creeks. Station 3 was immediately upstream from Stanford Golf Course and 500 meters downstream from site 4. Station 2 was 500 meters downstream from Stanford Golf Course. Station 1 was 433 meters downstream from station 2, and was the furthest point downstream where surface flow persists for the majority of the year. Conditions at each station were recorded on data sheets adapted from the EPA's Rapid Bioassessment Protocols (EPA 1989).

\section{Invertebrate Sampling}

Insect distribution and abundance was determined from six week artificial substrate colonization (two substrates per station, two replications per year). The multiplate artificial substrates used for collecting invertebrates consisted of eleven tiles of tempered masonite (19 square $\mathrm{cm}, 0.5 \mathrm{~cm}$ in width) assembled on a $20 \mathrm{~cm}$ central screw with varying distances between each plate provided by stainless steel washers. Plate spacing varied from $0.2 \mathrm{~cm}$ to $1.3 \mathrm{~cm}$. The total surface area of the eleven tiles was 1301 square centimeters. The substrates, two at each station, were placed in the stream at a 45 degree angle to flow and similar microhabitats were used at each site. They were secured to the stream bottom with a twelve-inch metal spike. The spike was attached to the sampler with water-proof wire and then driven into the stream bottom. A rock larger than $10 \mathrm{~cm}$ in diameter was placed on the instrument to avoid movement, direct sunlight, and theft. All stations were located in riffle habitats. Water depth, when sampling began at each station was equal to or greater than $9 \mathrm{~cm}$ but no greater than $20 \mathrm{~cm}$. Water depth greater than $9 \mathrm{~cm}$ ensured that the entire sampler would be surrounded by water for the entire collection period.

At station 1 the collection periods extended from 13 June to 24 July 1993 and 24 July to 20 August 1993. Flow at this station became intermittent and one substrate was lost at the end of the second colonization period during 1993. At stations 2 through 6 in 1993, the collection periods extended from 13 June to 24 July 1993 and 24 July 1993 to 4 September 1993. At station 7 the collection period was from 30 June to 7 August 1993. 
Reduced flow at this station in August precluded a second sampling. At station 8, in Jasper Ridge Ecological Preserve, the collection period was from 29 August to 2 October 1993. Access was not permitted into the Preserve until late in the 1993 collection year and, therefore, the station was sampled only once. In 1994, the collection period was from 30 March 1994 to 12 May 1994 and 12 May 1994 to 20 June 1994 at all stations.

After the six week colonization period, the samplers were carefully removed from the stream to avoid loss of insects and placed in a large plastic zip-lock bag. New samplers were placed in the stream at the same location for the next six week colonization period. All samplers were dismantled on the same day they were collected. Each plate was carefully cleaned and contents placed into a sorting pan. Insects collected from the sorting process were placed in glass jars with $95 \%$ ethanol. The catches were identified over a two month period using the keys of Merritt and Cummins (1984).

Statistical analysis for macroinvertebrates included invertebrate abundance and taxa richness between sites and years, ratio of EPT and Chironomidae abundances, and the Jaccard Coefficient of community similarity. Tolerance scores for families of invertebrates (Hilsenhoff 1988a) were utilized to relate invertebrate presence to stream conditions.

\section{Water Quality Sampling}

Data for dissolved oxygen, water temperature, and water depth were collected between 7:30 am and 6:00 pm on a weekly basis. Dissolved oxygen was measured with a LaMotte dissolved oxygen kit. Water samples were collected between the two samplers and analyzed for dissolved oxygen on-site. Water temperature was recorded on a weekly basis utilizing a Taylor maximum-minimum thermometer. The thermometers were secured to the stream bottom and covered with small rocks to avoid movement and theft. Water depth was recorded each week with a ruler.

In 1994, water samples were collected every two weeks, placed on ice, and analyzed at Scientific Environmental Laboratories of Palo Alto, California. Samples were tested for $\mathrm{pH}$, conductivity (UMHO/CM), turbidity (NTU), $\mathrm{NH}_{3}, \mathrm{NO}_{2}, \mathrm{NO}_{3}$, and $\mathrm{PO}_{4}$. For water years 1980-1994 stream discharge measurements were obtained from the United States Geological Survey (USGS) which has a stage recorder and concrete control on the stream. The recorder is located at Latitude 370 25'24", Longitude 1220 11'18' in Santa Clara County at Stanford Golf Course on the right bank $1.8 \mathrm{~km}$ downstream from Los Trancos Creek, and $1.4 \mathrm{~km}$ upstream of station 2. Rainfall data for 1980-1994 was 
obtained from the Santa Clara Valley Water District (SCVWD) and was measured at the Palo Alto monitoring station (2099). 


\section{CHAPTER 3}

\section{RESULTS OF WEEKLY TESTING}

Detailed site characteristics for May 1993 are presented for stations 1-8 in Appendix B. Abbreviated site characteristics are in Table 1. Stream width varied naturally between the sampling stations, and there was no relationship between sampling location (e.g., higher or lower in the watershed) and stream width and depth. All stations were represented by cobble substrates with varying degrees of boulders, gravel, sand, silt, and clay.

Table 1. Abbreviated Site Characteristics for Stations 1 through 5 and 7 and 8 on San Francisquito Creek and Station 6 on Los Trancos Creek for May 1993.

$\begin{array}{lrrrrrrrrr}\text { PARAMETERS } & \underline{1} & \underline{2} & \underline{3} & \underline{4} & \underline{5} & \underline{6} & \underline{1} & \underline{8} \\ \text { STREAM WIDTH (m) } & 15 & 11 & 15 & 8 & 14 & 5 & 14 & 14 \\ \text { STREAM DEPTH (m) } & 0.11 & 0.17 & 0.11 & 0.12 & 0.15 & 0.11 & 0.09 & 0.11 \\ \begin{array}{l}\text { SUBSTRATE } \\ \text { C COMPOSITION }\end{array} & & & & & & & & \\ \text { BOULDER >256 mm } & - & 30 & 25 & 30 & 50 & 30 & - & 50 \\ \text { COBBLE 64-256 mm } & 70 & 50 & 50 & 50 & 30 & 50 & 70 & 40 \\ \text { GRAVEL 2-64 mm } & - & - & - & 10 & - & 10 & 20 & 10 \\ \text { SAND 0.06-2.0 mm } & 10 & 10 & 20 & 10 & - & 10 & 10 & - \\ \text { SILT 0.004-0.06 mm } & 15 & 10 & 5 & - & 10 & - & - & - \\ \text { CLAY <0.004 mm } & 5 & - & - & - & 10 & - & - & -\end{array}$


Stream discharge and rainfall totals from 1980-1994 are presented in Table 2. Stream discharge data was obtained from the USGS stream gauge located approximately 1500 meters above station 2. Rainfall data was obtained from the SCVWD rain gage located in Palo Alto (2099).

Table 2. Monthly Range, Mean (+/-SD) and Number of Measurements ( $\mathrm{n}$ ) for Stream Discharge in San Francisquito Creek and Rainfall Within the Watershed, OctoberSeptember 1980-1994.

\begin{tabular}{llrrr} 
& RANGE & MEAN & N & TOTAL \\
\cline { 2 - 5 } STREAM DISCHARGE (cfs) & & & & \\
$1980-1992$ & $0.00-2,380$ & $23.6+/-29.1$ & 109 & \\
1993 & & & & \\
1994 & $0.08-1,620$ & $32.8+/-61.8$ & 12 & 11,877 \\
$19.03-262$ & $5.3+/-10.8$ & 12 & 1,853
\end{tabular}

RAINFALL (inches)

$\begin{array}{lllllll}1980-1992 & 0.00- & 8.56 & 1.27+/- & 1.84 & 109 & \\ 1993 & 0.00- & 6.79 & 1.69+/- & 2.34 & 12 & 20.28 \\ 1994 & 0.00- & 2.95 & 1.04+/- & 0.993 & 12 & 11.46\end{array}$

Stream discharge during the sampling periods of 1993 and 1994 is presented in Figures 2 and 3 respectively. The arrows in the charts represent the date on which the artificial substrates were removed from the stream for insect collection. In 1993, stream flow diminished steadily during the sampling regime but remained adequate except at stations 1 and 7 through September. On 13 June 1993, when sampling began, stream discharge at the USGS gage was $4.9 \mathrm{cfs}$. On 24 July 1993, the date of the first collection for stations $1-6$, stream discharge had receded to $1.1 \mathrm{cfs}$. Stream flow decreased to 0.13 cfs on 4 September 1993 the date of the second and last collection for sites 2-6. Discharge ceased at station 1 on 20 August 1993. No large increases in discharge were observed during the study in 1993.

In 1994, discharge was less persistent during the sampling period, a result of diminished rainfall during the 1993-94 water year. However, rainfall did occur during the study in 1994 which created discharge fluctuations. Discharge spikes were observed in the 
stream on 25 April, 7 May, and 17 May. On 30 March 1994, when sampling began, stream discharge was $5.7 \mathrm{cfs}$. On 12 May the date of the first collection stream discharge receded to $2.6 \mathrm{cfs}$. Stream discharge decreased to $0.29 \mathrm{cfs}$ on 20 June the date of the last collection. 


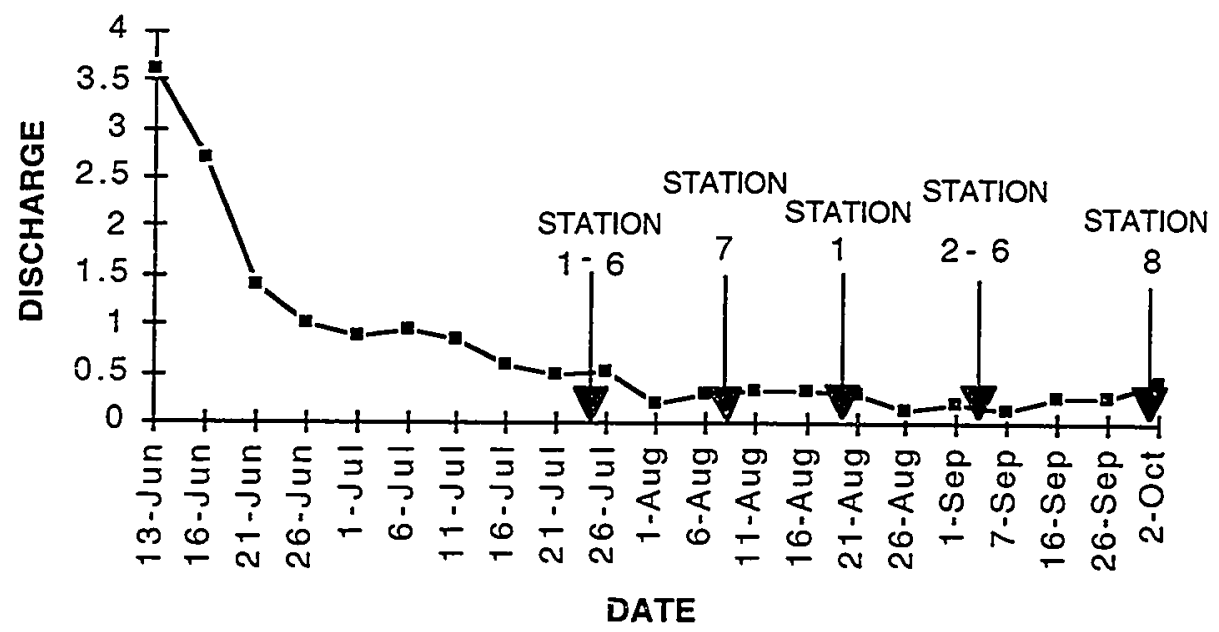

Figure 2. Discharge in San Francisquito Creek, 13 June-2 October and Collection Dates (->) 24 July (Stations 1-6), 7 August (Station 7), 20 August (Station 1), 4 September (Station 2-6), and 2 October (Station 8), 1993.

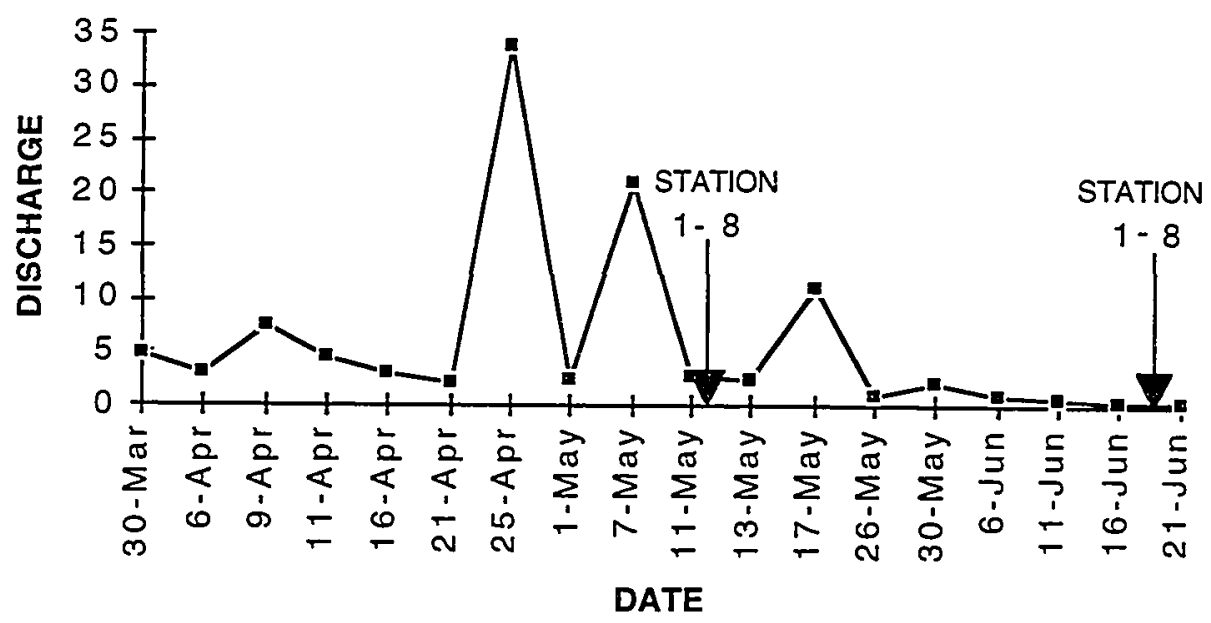

Figure 3. Discharge in San Francisquito Creek, 30 March-12 June, and Collection Dates $(->), 12$ May and 20 June 1994. 


\section{Water Qualitv Parameters}

Measurements of dissolved oxygen, maximum-minimum water temperature and stream depth measurements are presented in Appendix C for stations 1-8 for the 1993 and 1994 sampling years. Table 3 illustrates the difference in the range and mean for these parameters in the 1993 and 1994 sampling years.

\section{Dissolved Oxygen}

The concentration of dissolved oxygen (DO) in San Francisquito Creek was never seriously depleted, at least during the day when it was recorded. The percentage saturation never fell below $70 \%$ at any station in 1993 or 1994, except at station 8 . A minimum concentration of $6.0 \mathrm{ppm}$ ( $66 \%$ saturation) was recorded 29 August, and 4 September 1993, and 6.2 ppm (68\% saturation) 2 October 1993.

The highest average concentrations of DO were observed at Station 6 in Los Trancos Creek. Dissolved oxygen in 1993 and 1994 was never below 9.0 ppm (97\% saturation) at this location and the average concentration was $9.6 \mathrm{ppm}$.

\section{$\underline{\text { Water Temperature }}$}

The maximum and minimum water temperatures recorded between June and September 1993 and April and June 1994 increased as air temperature increased in both years. Mean water temperature when sampling began in 1993, was substantially higher $\left(60^{\circ} \mathrm{F}\right)$ than in $1994\left(50^{\circ} \mathrm{F}\right)$, a result of the sampling period beginning later in the year. The maximum water temperature was observed at station $1\left(81^{\circ} \mathrm{F}\right)$ and station $2\left(80^{\circ} \mathrm{F}\right)$ in 1993, and at station $1\left(76^{\circ} \mathrm{F}\right)$ in 1994. 


\section{$\underline{\text { Water Depth }}$}

Stream depth decreased during the sampling year in 1993 and in 1994 as the dry season progressed. Bear Creek was intermittent by May in both study years. Diversions on Los Trancos Creek occurred through April, reducing the amount of water received by San Francisquito during the early part of the 1994 study.

Table 3. Range, Mean ( $+/-S D)$ and Number of Measurements for Dissolved Oxygen and Water Temperature at Stations 1-8 in 1993 and 1994.

$\underline{1993}$

$\begin{array}{lcccc} & \text { RANGE } & \text { MEAN } & \text { N } \\ \text { DISSOLVED OXYGEN (ppm) } & 6-11.8 & 8.2+/-1.22 & 72 \\ \text { MAXIMUM WATER TEMPERATURE (F0) } & 61-81 & 69.9+/-4.32 & 65 \\ \text { MINIMUM WATER TEMPERATURE (FO) } & 54-65 & 60.4+1-1.88 & 65\end{array}$

1994

RANGE MEAN $\quad \underline{N}$

$\begin{array}{lllll}\text { DISSOLVED OXYGEN (ppm) } & 7-13.3 & 10.3+/- & 1.24 & 78\end{array}$

MAXIMUM WATER TEMPERATURE $\left(F^{0}\right) \quad 61-81 \quad 64.8+/-4.41 \quad 78$

MINIMUM WATER TEMPERATURE (FO) $\quad 49-64 \quad 54.7+/-3.22 \quad 78$ 
$\underline{\mathrm{pH}}$

The range of $\mathrm{pH}$ in San Francisquito Creek was 7.7 to 8.4 throughout the study at all stations. The prevalence of limestone in the geology of Santa Clara County, acts as a buffering property in the regions streams.

Turbidity

Turbidity ranged from 0.01-3.4 (NTU) in 1994. There was no correlation between location in the stream and turbidity recordings during the study. Turbidity did increase in time over the year but levels observed during the study are considered relatively minor (Whiting and Clifford 1983) and at least during the study period never high enough to be detrimental to aquatic life.

\section{Conductivitv}

Conductivity, the amount of ions dissolved in water, ranged from 691-1360 (UMHO/CM) but was consistently higher at station 6 . Conductivity in streams is considered a minor variable in most instances, but often correlates with buffering capacity and nutrient levels.

\section{Nitrites}

Levels of $\mathrm{NO}_{2}(\mathrm{ppm})$, the intermediate ion between $\mathrm{NH}_{3}$ and $\mathrm{NO}_{3}$, were never above 0.05 (ppm) at any station in 1994.

\section{Nitrates}

The range (ppm), mean (ppm) and number of measurements for nitrates, phosphates, and ammonia are presented in Table 4. Stations 1-6 continually showed higher nitrate levels during the study. Beginning in April through the middle of June, nitrate levels ranged between $2.3 \mathrm{ppm}$ and $5.6 \mathrm{ppm}$ with the lower concentrations always observed at stations 7 and 8. On 31 May 1994 a high concentration of $9.0 \mathrm{ppm}$ in nitrates was recorded at station 6 and elevated nitrate levels were observed at all stations. 
Ammonia

Concentration of $\mathrm{NH}_{3}$ was $<0.3$ (ppm) through 31 May 1994 at all stations. On 13 June, however, concentrations of $\mathrm{NH} 3$ ranged from $0.30-0.59$ at all stations.

\section{Phosphates}

Phosphate oxidizes very readily and occurs in the earth's rocks most commonly as orthophosphate. The main source of this ion is igneous rocks containing the phosphatic mineral, appatite (Cole 1983). Through 2 May, 1994 phosphorus levels were $<0.05$ (ppm). As the year progressed, however, elevated levels were recorded at all stations. . 
Table 4. Range, Mean, (+/-) SD and Number of Measurements (n) for $\mathrm{NO}_{3}, \mathrm{NH}_{3}, \mathrm{PO}_{4}$ at Stations 1-8, 4 April-13 June 1994.

\begin{tabular}{|c|c|c|c|c|c|c|}
\hline & Station 1 & & & Station 2 & & \\
\hline & Range & Mean & $n$ & Range & Mean & $\mathrm{n}$ \\
\hline NO3 (ppm) & $4.9-5.4$ & 5.1 & 6 & $4.6-5.6$ & 5.1 & 6 \\
\hline $\mathrm{NH3}$ (ppm) & $0.0-3.7$ & 0.09 & 6 & $0.0-0.6$ & 0.18 & 6 \\
\hline PO4 (ppm) & $0.0-0.2$ & 0.05 & 6 & $0.0-0.3$ & 0.09 & 6 \\
\hline & Station 3 & & & Station 4 & & \\
\hline & Range & Mean & $n$ & Range & Mean & $\mathrm{n}$ \\
\hline NO3 (ppm) & $4.8-5.6$ & 5.1 & 6 & $4.8-5.7$ & 5.2 & 6 \\
\hline NH3 (ppm) & $0.0-0.3$ & 0.12 & 6 & $0.0-0.3$ & 0.12 & 6 \\
\hline PO4 (ppm) & $0.0-0.2$ & 0.08 & 6 & $0.0-0.2$ & 0.07 & 6 \\
\hline & Station 5 & & & Station 6 & & \\
\hline & Range & Mean & $n$ & Range & Mean & $n$ \\
\hline NO3 (ppm) & $4.7-5.6$ & 5.1 & 6 & $4.5-9.0$ & 5.6 & 6 \\
\hline NH3 (ppm) & $0.0-0.3$ & 0.11 & 6 & $0.0-0.3$ & 0.12 & 6 \\
\hline PO4 (ppm) & $0.0-0.2$ & 0.08 & 6 & $0.0-0.3$ & 0.09 & 6 \\
\hline & Station 7 & & & Station 8 & & \\
\hline & Range & Mean & $\mathrm{n}$ & Range & Mean & n \\
\hline NO3 (ppm) & $2.0-5.1$ & 3.0 & 6 & $2.1-5.0$ & 2.8 & 6 \\
\hline $\mathrm{NH} 3$ (ppm) & $0.0-0.4$ & 0.11 & 6 & $0.0-0.4$ & 0.11 & 6 \\
\hline PO4 (ppm) & $0.0-0.2$ & 0.07 & 6 & $0.0-0.2$ & 0.6 & 6 \\
\hline
\end{tabular}




\section{Aquatic Insect Abundance and Richness by Station in}

\section{San Francisquito Creek in 1993}

Insects were collected during two sample periods in 1993: June to July or early August for stations 1-7 and late July to September for stations 1-6 (Table 5). A late August-October sample at station 8 was also included with the late sample group. A total of 298 insects, of 15 families were collected in 1993 from 27, six week sets of artificial substrates.

Early Summer Collection: Stations 1-6. June 13-24 July 1993. Station 7. June 30-7 August 1993.

At Station 7, a total of seven insects from 4 families were collected from the one sampling in 1993. Diptera Chironomidae (43\%) was present along with the Trichopterans Lepidistomidae (29\%) and Limnophilidae (14\%). The very pollution intolerant Megaloptera Corydalidae (14\%) was also present.

At station 6, four invertebrates were collected represented by Trichopteran families that are indicators of relatively good water quality: Lepidistomidae, Uenoidae and Limnophilidae.

Station 5 had a total of 33 insects in the first collection of 1993: Most were from the Order Trichoptera: Hydropsychidae (64\%), Limnophilidae (12\%), Lepidistomidae (9\%). Chironomidae represented $6 \%$ of the collection.

Station 4 had a total of 19 insects, dominated by Chironomidae with $58 \%$. Limnophilidae, and Lepidistomidae each contributed $16 \%$.

Station 3 had a total of 80 insects, dominated by Limnophilidae (53\%), Hydropsychidae (45\%). One Plecopteran from the family Perlidae was also collected.

Station 2, had a total of 23 insects, dominated by Chironomidae (65\%), Uenoidae (13\%), and Muscidae (13\%).

Station 1 had a total of 8 insects, with Chironomidae representing $75 \%$, and the Odonata family, Coengrionidae $25 \%$.

Overall, during the early summer sampling Chironomids (21\%) and Trichopterans (72\%) dominated the collections. 
Late Summer Collection: Stations 1-6. July 24-4 September. 1993. Station 8. August 29-2 October, 1993

At station 8 , five insects were collected. This sample included 4 Odonata of the very pollution tolerant family Coengrionidae and 1 Trichoptera Lepidistomidae.

At station 6, eight insects were collected from the late summer samples. Lepidistomidae increased from 1 to 7 and dominated the collection. One Coengrionidae was also collected.

Station 5 had a total of 11 insects in the second collection versus 33 in the early summer samples. The intolerant families Limnophilidae (27\%), Perlidae (18\%), and the tolerant family Coengrionidae (18\%), were most abundant. Six of the seven families in this sample had not been collected earlier at the site.

Station 4 had a total of 21 insects in the late summer samples. Twenty were from the family Limnophilidae.

Station 3 had a total of 41 insects in the late summer sample with Limnophilidae (61\%), and Hydropsychidae (34\%) dominant as in the early summer samples.

Station 2, had a total of 26 insects in the second collection. Most abundant were tolerant Odonata of the family Coengrionidae (50\%). Chironomidae (42\%) which dominated in early summer samples remained abundant.

Station 1 had a total of 7 insects from a single substrate in the second collection. Six Chironomidae were present along with one Limnophilidae.

Overall in 1993 family richness was highest at station 5 (Table 6, Figure 4), upstream of Los Trancos Creek, with 12 families represented. The station also had the highest family diversity in the early samples (6) and late samples (7), but displayed almost a complete turnover in families; only the Trichoptera family Limnophilidae was present in both collections. 
Table 5. Total Number of Insects collected, Number of Samples, in Early Summer (E) 1993, 13 June-24 July (Stations 1-6) 30 June-7 August (Station 7) and Late Summer (L) 1993, 24 July-4 September (Stations 1-6), 29 August-2 October (Station 8) (Hilsenhoff Rating [1988a] in Parenthesis Following Insect Family) ND Indicates Hilsenhoff Score not Available.

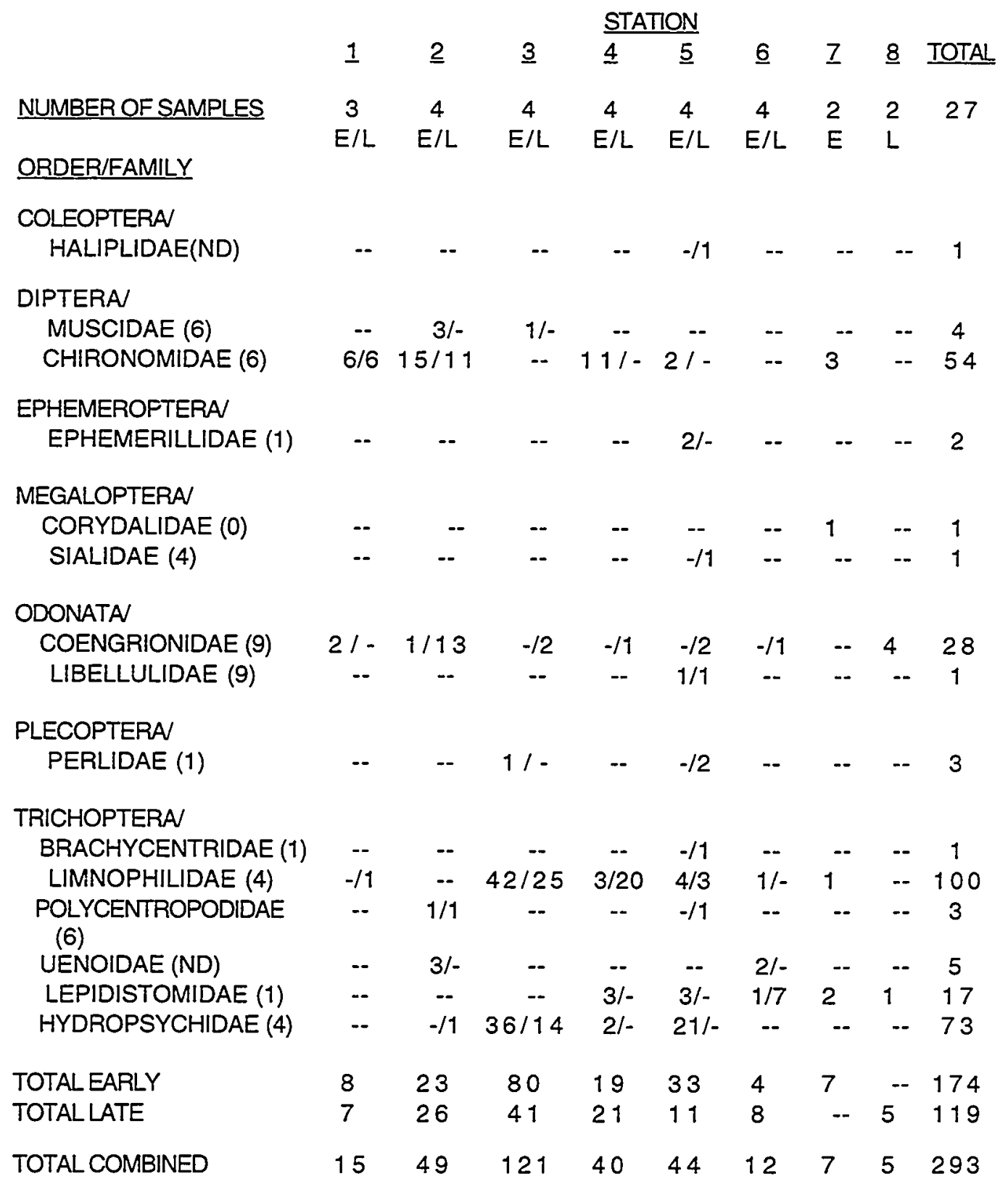


Table 6. Family Richness, by Order, for San Francisquito Creek, June-October 1993.

\begin{tabular}{lllllllll} 
ORDER & \multicolumn{7}{c}{ STATION } & \\
& 1 & 2 & 3 & 4 & 5 & 6 & 7 & 8 \\
COLEOPTERA & 0 & 0 & 0 & 0 & 1 & 0 & 0 & 0 \\
DIPTERA & 1 & 2 & 1 & 1 & 2 & 0 & 1 & 0 \\
EPHEMEROPTERA & 0 & 0 & 0 & 0 & 1 & 0 & 0 & 0 \\
MEGALOPTERA & 0 & 0 & 0 & 0 & 1 & 0 & 1 & 0 \\
PLECCPTERA & 0 & 0 & 1 & 0 & 1 & 0 & 0 & 0 \\
TRICHOPTERA & 1 & 3 & 2 & 3 & 5 & 3 & 2 & 1 \\
ODONATA & 1 & 1 & 1 & 1 & 1 & 1 & 0 & 1 \\
TOTAL & 3 & 6 & 5 & 5 & 12 & 4 & 4 & 2
\end{tabular}




\section{Aquatic Insect Abundance and Richness bv Station in}

San Francisquito Creek in 1994

Total abundance and taxa richness by family of stream insects in San Francisquito Creek for 1994 are presented in Tables 7 and 8. In 1994, sampling began on 31 April at all stations in San Francisquito Creek. During the early spring sampling 348 insects were collected and 56 during the late spring sampling.

Earlv Spring Collection: Stations 1-8, March 30-12 Mav, 1994

In the first collection at Station 8 of 1994, 4 insects were collected, all in the tolerant Odonata family Coengrionidae.

Station 7 samples had 215 insects after the first collection. The current dependent Diptera Simulidae dominated the collection at 213; two Ephemeroptera from the family Heptageniidae were also collected.

At Station 6, eleven insects were collected dominated by the pollution sensitive Trichopterans: Limnophilidae (45\%) and Brachycentridae (27\%).

In the early sampling at station 5 , eighty-nine insects were collected. Diptera Simulidae (83\%) was the dominant taxa. Other insects included Ephemeropterans Siphlonuridae (7\%), and Ephemerillidae (6\%).

At station 4 , total insect abundance was 22 in the early collection. Simulidae (68\%) were the most abundant.

In the early collection at station 3 in 1994, Trichopterans: Hydropsychidae (64\%) and Limnophilidae (14\%) were most abundant along with Diptera Simulidae (14\%).

At station 2, six insects were collected in the early samples. Odonata Coengrionidae (33\%) and Ephemeroptera Heptageniidae (33\%) were most abundant.

At station 1, thirty-eight insects were collected in the early sampling. Dipterans Simulidae (52\%), Ceratopogonidae (24\%), and Ephemeroptera Siphlonuridae (24\%) were in the sample.

Overall, during the early spring sampling Simulidae (79\%) dominated the collections followed by Trichopterans (7\%). 
Late Spring Collection: Stations 1-8. May 12-20 June, 1994

Insect abundance at station 8 increased from four in the early collection to fifty-eight in the late collection of 1994. Trichoptera Hydropsychidae (71\%), which was absent in the early samples was the most abundant. Other insects added from the first collection were Diptera Tipulidae, and Trichoptera Brachycentridae.

At station 7, eight insects were collected in the late spring sampling in 1994; four Diptera Chironomidae, three Brachycentridae, and one Ephemeroptera Leptophlebidae. There was also a complete loss of Simulidae, which were abundant in the early spring collection.

Station 6 had one insect in the late spring sample of 1994, down from ten insects collected in the early spring. The one Coengrionidae collected was not among the insects collected in the first sample.

Station 5 had three insects in the late spring sample; all of which were families not collected in the earlier sampling. Abundance at this station dropped from the thirty-nine insects collected in the early sample. Insects absent in this collection included Simulidae, Limnophilidae, and several families of Ephemeroptera.

At station 4, three insects were collected in the late samples, including one Trichoptera Brachycentridae and two Coengrionidae.

Station 3 had 4 insects in the late spring collection of 1994, compared to 14 in the early collection.

Station 2 , also had 4 insects in the late collection of 1994 represented solely by Coengrionidae.

At station 1, seven insects were collected in the late sampling; including two Chironomidae, two Hydropsychidae and one Plecoptera Perlidae.

Overall in 1994, family richness was highest at station 5 (Table 8, Figure 5), upstream of Los Trancos Creek, with 9 families represented. The station also had the highest family diversity in the early samples (6), which were replaced by three new families in the late sample. At all stations there was almost a complete changeover in families between early and late samples (Figure 5). All stations except station 8 exhibited a drop in abundance from the early samples. Most notably was the absence of Simulidae, which was dominant in many of the early samples (274), but almost absent in the late sample (1). 
Table 7. Total Number of Insects collected, Number of Samples, in Early Spring (E) 1994, 30 March-12 May (Stations 1-8) and Late Spring (L) 1994, 12 May-20 June (Stations 1-8) (Hilsenhoff [1988a] Rating in Parenthesis Following Insect Family) ND Indicates Hilsenhoff Score not Available.

\begin{tabular}{|c|c|c|c|c|c|c|c|c|c|}
\hline & \multicolumn{7}{|c|}{ STATION } & \multirow[b]{2}{*}{8} & \multirow[b]{2}{*}{ TOTAL } \\
\hline & 1 & 2 & 3 & 4 & 5 & 6 & 7 & & \\
\hline $\begin{array}{l}\text { NUMBER OF SAMPLES } \\
\text { ORDER/FAMILY }\end{array}$ & $\begin{array}{c}4 \\
E / L\end{array}$ & $\begin{array}{c}4 \\
E / L\end{array}$ & $\begin{array}{c}4 \\
E / L\end{array}$ & $\begin{array}{c}4 \\
E / L\end{array}$ & $\begin{array}{c}4 \\
E / L\end{array}$ & $\begin{array}{c}4 \\
E / L\end{array}$ & $\begin{array}{c}4 \\
E / L\end{array}$ & $\begin{array}{c}4 \\
E / L\end{array}$ & 32 \\
\hline $\begin{array}{l}\text { COLEOPTERA } \\
\text { HALIPLIDAE (ND) }\end{array}$ & -- & -- & -- & -- & $-/ 1$ & -- & -- & -- & 1 \\
\hline DIPTERA & & & & & & & & & \\
\hline $\begin{array}{l}\text { CERATOPOGONIDAE } \\
(6)\end{array}$ & 9/- & -- & -- & -- & -- & -- & -- & -- & 9 \\
\hline CHIRONOMIDAE (6) & $-/ 2$ & -- & -- & -- & -- & -- & -14 & -- & 6 \\
\hline DOLICHOPODIDAE (4) & -- & -- & $-/ 1$ & -- & -- & - & -- & -- & 1 \\
\hline SIMULIDAE (6) & $20 / 1$ & -- & $2 /-$ & $15 /-$ & $24 /-$ & -- & $213 /-$ & -- & 275 \\
\hline TIPULIDAE & -- & -- & -- & -- & -- & -- & -- & $-/ 1$ & 1 \\
\hline EPHEMEROPTERA & & & & & & & & & \\
\hline BAETIDAE (4) & -- & $1 /-$ & -- & -- & $1 /-$ & $1 /-$ & $-\cdot$ & -- & 3 \\
\hline EPHEMERILLIDAE (1) & -- & -- & -- & $1 /-$ & $5 /-$ & -- & -- & -- & 6 \\
\hline HEPTAGENIIDAE (4) & -- & $2 /-$ & -- & -- & $1 /-$ & -- & $2 /-$ & -- & 5 \\
\hline LEPTOPHLEBIDAE (2) & -- & -- & -- & -- & -- & -- & $-/ 1$ & -- & 1 \\
\hline SIPHLONURIDAE (7) & $9 /-$ & $1 /-$ & $1 /-$ & $4 /-$ & $6 /-$ & $1 /-$ & -- & -- & 22 \\
\hline ODONATA & & & & & & & & & \\
\hline COENGRIONIDAE (9) & $-/ 1$ & $2 / 4$ & $-/ 1$ & -12 & -11 & $-/ 1$ & -- & $4 / 6$ & 22 \\
\hline $\begin{array}{l}\text { PLECOPTERA } \\
\text { PERLIDAE (1) }\end{array}$ & -11 & & 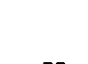 & & & & & & \\
\hline TRICHOPTERA & & & & & & & & & \\
\hline $\begin{array}{l}\text { BRACHYCENTRIDAE } \\
\text { (1) }\end{array}$ & -- & -- & -- & $-/ 1$ & -- & $3 /-$ & $-/ 3$ & -16 & 13 \\
\hline HYDROPSYCHIDAE (4) & $-/ 2$ & -- & 9/- & $1 /-$ & -11 & -- & -- & $-/ 13$ & 26 \\
\hline LIMNOPHILIDAE (4) & -- & -- & $2 /-$ & $1 /-$ & $2 /-$ & $5 /-$ & -- & -- & 10 \\
\hline RHYACOPHILIDAE (0) & -- & -- & -12 & -- & -- & -- & -- & -- & 2 \\
\hline TOTALEARLY & 38 & 6 & 14 & 22 & 39 & 10 & 215 & 4 & 348 \\
\hline TOTALLATE & 7 & 4 & 4 & 3 & 3 & 1 & 8 & 26 & 56 \\
\hline TOTAL COMBINED & 45 & 10 & 18 & 25 & 42 & 11 & 223 & 30 & 397 \\
\hline
\end{tabular}


Table 8. Family Richness, by Order, for San Francisquito Creek, April-June in 1994.

\begin{tabular}{lllllllll} 
ORDER & \multicolumn{7}{c}{ STATION } \\
& 1 & 2 & 3 & 4 & 5 & 6 & 7 & 8 \\
COLEOPTERA & 0 & 0 & 0 & 0 & 1 & 0 & 0 & 0 \\
DIPTERA & 3 & 0 & 2 & 1 & 1 & 0 & 2 & 1 \\
EPHEMEROPTERA & 2 & 3 & 1 & 2 & 4 & 2 & 2 & 0 \\
PLECOPTERA & 1 & 0 & 0 & 0 & 0 & 0 & 0 & 0 \\
TRICHOPTERA & 1 & 0 & 3 & 3 & 2 & 2 & 1 & 2 \\
ODONATA & 1 & 1 & 1 & 1 & 1 & 1 & 0 & 1 \\
TOTAL & 8 & 4 & 7 & 7 & 9 & 5 & 5 & 4
\end{tabular}




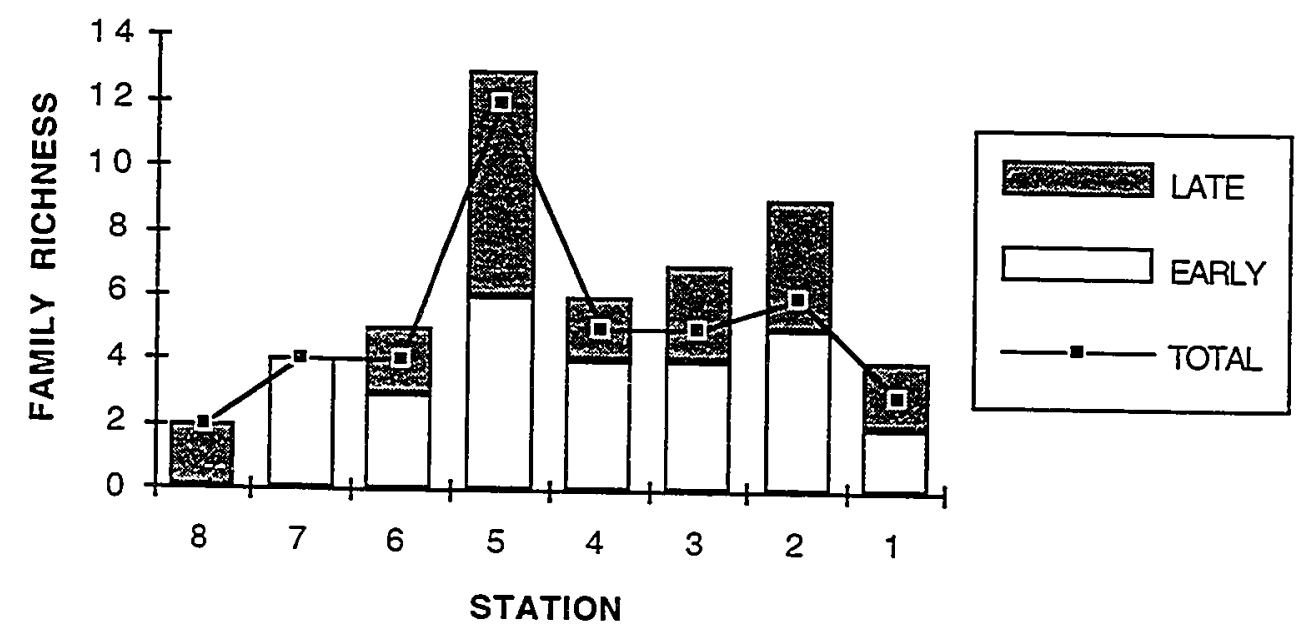

Figure 4. Family Richness of Stream Insects at Stations 1-8 in San Francisquito Creek, in Early Summer 1993: 13 June-24 July (Stations 1-6), 30 June-7 August (Station 7); and Late Summer 1993: 24 July-4 September (Stations 1-6), 29 August-2 October (Station 8); and Total Family Richness in 1993.

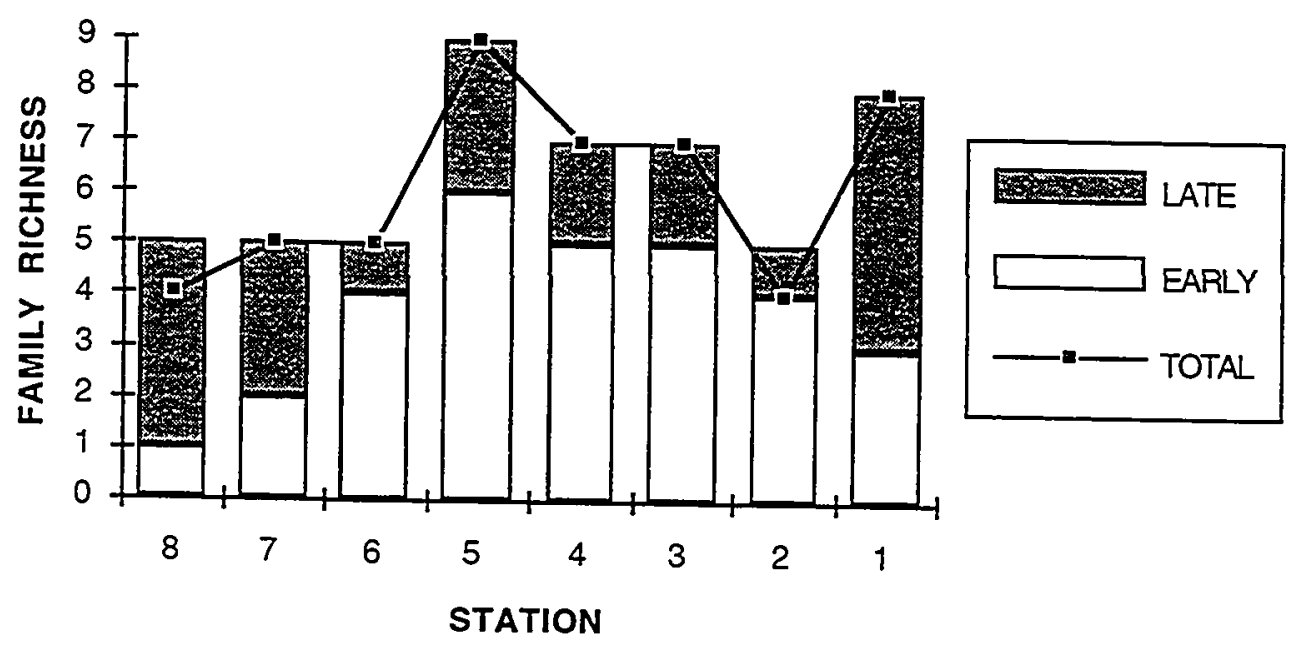

Figure 5. Family Richness of Stream Insects at Stations 1-8 in San Francisquito Creek, in Early Spring 1994: 30 March-12 May (Stations 1-8) and Late Spring 1994: 12 May-20 June (Stations 1-8), and Total Family Richness in 1994. 


\section{CHAPTER 4 DISCUSSION}

\section{Factors Resulting in Stream Insect Distribution and Abundance in} 1993 and 1994

Annual production of invertebrates in San Francisquito Creek depends on a number of biotic and abiotic variables. These include temperature, stream flow, nutrients and the amount of available food. Also, total abundance will be affected by the timing of the emergence of adults, which occurred throughout the sampling period. The greatest emergence is from May through September depending on the species. Decreases in abundance linked to emergence were estimated, since it is virtually impossible to understand the exact emergence times when identifying to the family level (Merritt and Cummins 1984,43 ).

The similarity between the species composition of the early and late summer collections in 1993, early and late spring collections in 1994, and 1993 to 1994 was tested with the Jaccard Co-efficient of Similarity Index. Index values can range from 0 , indicating no similarity, to 1 , indicating identical communities. When all taxa were compared for early and late summer collections in 1993 the Index value was 0.47, showing a fairly low level of similarity between the two collections. Comparing only EPT taxa, the similarity between the two collections was 0.63 , indicating that conditions, at least for EPT taxa, remained relatively constant. When all taxa were compared between the early spring and late spring for 1994 collection the Index value was 0.24 , showing a very low level of similarity between the two collections. Comparing only EPT taxa, the similarity between the two collections was 0.20 , indicating that stream conditions and consequently species composition were very different between the two collections. Overall collections in 1993 versus 1994 showed a similarity of 0.40 . Comparing only EPT taxa showed a similarity of 0.38. Differences seen between collection times within the same year showed similarities near or lower than those between a wet year (1993) and a dry year (1994). 
The average number of organisms collected per station in 1993 was 39 and in 1994 the number was 60 . The higher numbers for 1994 were due to the large populations of Simulidae present in the stream, especially at station 7 during the first collection. Without Simulidae average numbers were much less. The average number of families collected per station in 1993 was 5, and that number in 1994 was 6 . Based on taxa richness data, it appears that San Francisquito Creek was not much different during the collections in 1993 and 1994. In 1994, taxa richness did not change considerably between the two collections but species common to both samples did, with almost a complete turnover of species between early spring and late spring samples (Table 7, Figure 5). There is also a dramatic difference in abundance from early to late collections in 1994.

In 1993, five insects collected from two artificial substrates at station 8 in the one late summer sampling period (29 August-2 October). In 1994, thirty insects were collected in two sampling periods (30 March-12 May and 12 May-20 June). In the first sampling period four insects were collected, and in the second sampling period twenty-six insects were collected, $50 \%$ of which were Hydropsychidae. The differences in abundance between years and between collections in the same year at this station are primarily a result of seasonal differences associated with the collections. In 1993, sampling began in August and ended in October. Because of the late sampling many species of insects had probably already emerged as adults. The Trichopteran Hydropsychidae, which was identified at this station in 1994, emerges throughout the summer, and was missed by the late sampling. In 1994, the first sampling began in March and ended in May, probably too early in the life cycle for early instars to be collected from the substrates. The second collection, however, ended in June and abundance rose from 4 to 26 due to the presence of Hydropsychidae.

At station 7, seven insects were collected from two artificial substrates during the six week colonization of 1993 (30 June-7 August) including one Megaloptera: Corydalidae. Corydalidae larvae in intermittent streams burrow into the stream bed when surface water dries up; growth only occurs in the wet cycle so larval duration may be 3-4 years (semivoltine), depending on the annual duration of stream flow (Merritt and Cummins 1984, 261).

Insect abundance at station 7 in 1994, was 215 in the first sampling period, almost entirely as a result of Simulidae. Simulidae or blackflies are filter feeders and require high stream flow to filter food particles from the water column. In most aquatic habitats Simulidae are multivoltine (emerge as adults several times in a single year). They first appeared in San Francisquito in early April in a variety of growth stages (larvae, pupae, 
adult) and by June the majority had completed their life cycle and departed the stream as flows declined. In the second sampling of 1994 overall abundance had dropped to eight insects and Simulidae were absent.

Simulidae or black flies are among the most important insect pests of human and animals in many parts of the world because of their role as vectors of certain parasitic desease organisms and the irritation, and the toxic and the allergic manifestations of their bite (Merritt and Cummins 1983, 534). Because of these factors, they have a marked impact on the economy of many regions of the world. Although the life cycle for most black flies is similar, much remains to be learned about individual species. The female is ready to mate and oviposit usually after egg maturation, for which a blood meal is often required. However, mating can occur shortly after emergence or just before oviposition and takes place in flight or while landed. The abundance of blackflies in early 1994 was probably related to high discharges observed in the spring and/or the proliferation of cattle and horses, supplying a blood meal, near the stream. Also, the artificial substrates may have been selectively colonized by Simulidae, since they usually occur in a patchy distribution in streams.

At station 6, four insects were collected during the first six week colonization period of 1993 (13 June-17 July). In the second sampling period (17 July-7 September) eight insects were collected. In 1994, abundance was ten after the first six week colonization period (30 March-12 May) and one in the second (12 May-20 June). Water diversions from 1 December to 30 April from Los Trancos Creek for Felt Lake and the Lagunita Canal are probably a major cause of the low abundance at this station. Water quality appears to be very good, since $91 \%$ of all insects collected were EPT taxa. However, the effects of low flows can be witnessed by the absence of flow dependent Simulidae at this station when they were abundant at nearby stations 5 and 4 during the same period (30 March-12 May) of 1994.

Progressing downstream, stations 5, 4, and 3, exhibited the greatest abundance of sensitive forms of macroinvertebrates in 1993. It appears that this section of stream may fulfill the biotic and abiotic factors that stream insects prefer, providing in-stream plant growth and stream flow.

Station 5 had a total of 33 insects in the first collection of 1993 (13 June-17 July). In the second collection (17 July-7 September) abundance had dropped to eleven. The drop in abundance was probably a result of the emergence of Hydropsychidae which dominated the first collection but was absent in the second. In the first collection of 1994 , 
insect abundance was thirty-nine, $62 \%$ of which was Simulidae. In the second collection, overall abundance dropped to three. At this station and at stations 1 through 4 abundance dropped dramatically from the first collection to the second in 1994, and abundances were very low compared to those observed in 1993.

The drop in abundance at these stations was almost certainly a result of fluctuations in stream discharge. Although many other factors can affect invertebrate populations, stream flow appears to have had the greatest impact in San Francisquito Creek in 1994. Late spring storms probably removed those insects that are susceptible to removal because of their physical characteristics and univoltine (emerge as adults once a year) life cycle. Immature larval forms of Hydropsychidae and Limnophilidae (the most abundant insects at station 3-5 in 1993) are filterers and grazers and early or middle instars can be removed by sudden increases in stream discharge associated with storms. Prior to pupation late instars typically move from exposed, stream facing rock surfaces and select a protected site, such as under a stone or crevice of wood, and attach a case with silk (Feminella and Resh 1990). Once a case is constructed the larvae are less likely to be removed by sudden increases in stream discharge.

The fluctuation in discharge observed in 1994 is difficult to relate to insect abundance at station 6 due to diversions experienced on Los Trancos. Station 7 is naturally low in abundance as a result of low flows. Station 8 in 1994, appeared unaffected by the unseasonable rainstorms, probably because storm peaks are regulated by Searsville Dam.

Station 4 had 19 insects in the first collection and 21 insects in the second collection of 1993. Limnophilidae dominated the second collection (95\%). Chironomidae which were the most abundant family in the early collection were absent in the late collection. The absence of Chironomidae is probably related to decreases in algae at the station in during late sample period. The species of Limnophilidae that resulted in the increase may have a slightly later emergence time than Hydropsychidae, which exhibited a decrease in abundance between sampling regimes at other stations in 1993. In 1994, insect abundance was 22 in the first collection and dominated by Simulidae at $68 \%$. In the second collection abundance had dropped to 3 due to loss of Simulidae as flows declined.

Station 3 had the greatest abundance of invertebrates observed at any station in 1993 with 80 insects in the first collection and 41 in the second. The Trichopterans, Limnophilidae and Hydropsychidae dominated both collections. The drop in abundance appeared to be a product of emergence. In 1994, abundance was 14 in the first collection and 4 in the second. Trichopterans: Limnophilidae, 14\%, and Hydropsychidae, 64\%, 
dominated the first collection. In the second collection of 1994, Limnophilidae and Hydropsychidae were absent possibly due to emergence or declining stream flow.

Station 2, had a total of 23 insects in the first collection of 1993, dominated by Chironomidae (65\%). In the second collection of 1993, 26 insects were identified; Chironomidae, $42 \%$, and Coengrionidae, $50 \%$, were the abundant taxa. The abundance of these tolerant families during both collections suggests that the stream conditions were relatively poor at this downstream station. In 1994, abundance was only 6 after the first collection and 4 after the second. The tolerant family Coengrionidae was dominant in both collections, again suggesting relatively poor water quality.

Chironomidae represented $75 \%$ of the 8 insects in the first collection at station 1 in 1993. The other family occurring at station 1 , Coengrionidae is also very tolerant to suboptimal conditions. In the second collection of 1993 abundance was 7 from one substrate, six Chironomidae and one Limnophilidae. In 1994, abundance in the first collection at this station was 38, and included Simulidae 53\%, Diptera Ceretopogonidae 24\%, and Ephemeroptera Siphlonuridae 24\%. In the second collection of 1994 abundance had dropped to 7 , again probably a result of low discharge or fluctuations in discharge..

\section{Ratio of EPT and Chironomidae Abundance for Early Summer and Late Summer}

\section{Collections in 1993.}

The EPT and Chironomidae abundance ratio uses relative abundance of these indicator groups as a measure of community balance. Good biotic condition is reflected in communities having a fairly even distribution among all four major groups and with substantial representation in the sensitive groups Ephemeroptera, Plecoptera, and Trichoptera (EPT). Skewed populations having a disproportionate number of the generally pollution tolerant Chironomidae relative to the more sensitive insect groups may indicate environmental stress (Ferrington 1987). Certain species of some genera are highly tolerant of poor water quality (Lenat 1983, Mount et al. 1984), opportunistic, and may become numerically dominant in habitats experiencing environmental stress, EPT taxa are rare, indicating degraded conditions (Winner et al. 1980).

Chironomids tend to become increasingly dominant in terms of percent taxonomic composition and relative abundance along a gradient of increasing enrichment or heavy metals concentration (Ferrington 1987). 
Filamentous algae may be regarded as an indicator of enriched conditions in streams (Hynes 1960; Whitton 1970; Pitcairn and Hawkes 1973). Diptera Chironomidae is one the first macroinvertebrates to colonize running water containing organic or substantial inorganic enrichment (Gower and Buckland 1978). The reasons for this include the selection of sites by ovipositing females, and the semivoltine life cycle which provides repeated opportunities during the year when this species can invade streams which are suitable for its development.

San Francisquito Creek flows through agricultural land from station 7 to station 1, so there may be substantial runoff of fertilizers and waste from domestic animals. Growths of filamentous algae were present at stations 1 through 5 and 7 . However, the algal filaments were noticeably longer at stations 1 and 2 . 


\section{EPT AND CHIRONOMID ABUNDANCE, COLLECTION 1, 1993}

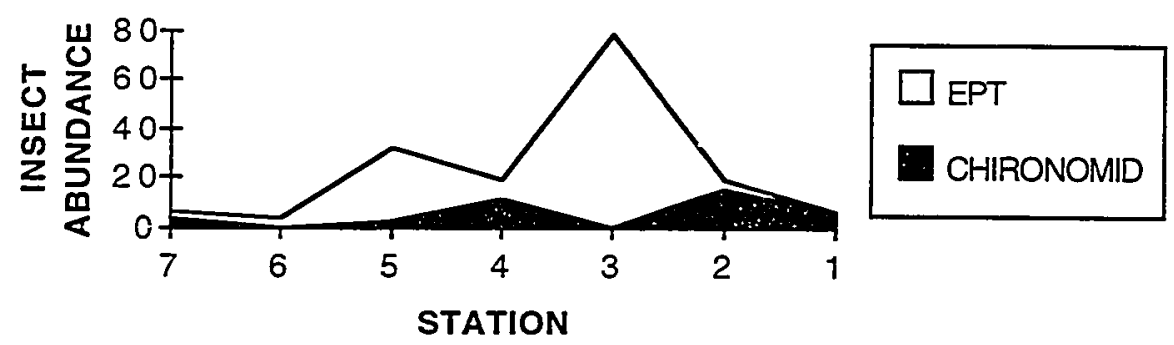

Figure 6. EPT/Chironomid Abundance in Early Summer 1993 at Stations 1-6, June 13-24 July, Station 7, 30 June-7 August

\section{EPT AND CHIRONOMID ABUNDANCE, COLLECTION 2, 1993}

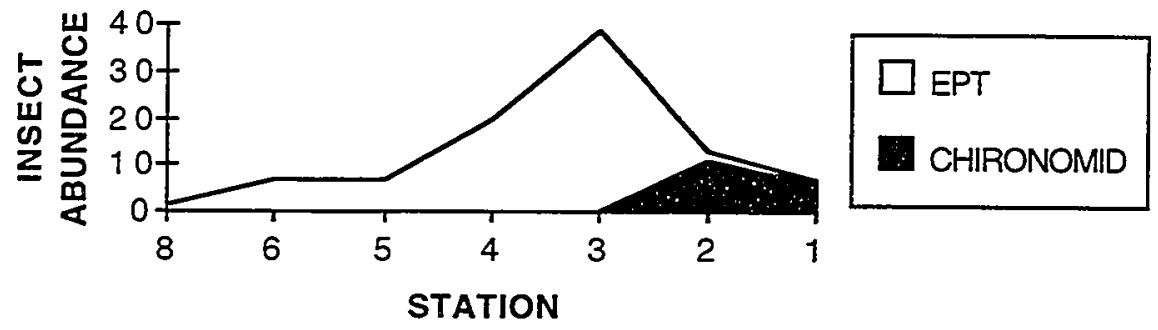

Figure 7. EPT/Chironomid Abundance in Late Summer 1993 at Stations 1-6, 24 July4 September, Station 8, 29 August-2 October. 
In 1993, the percentage of Chironomids to total number of insects was $18 \%$. EPT taxa represented $67 \%$ of the total. However, there were definite differences in the EPT/Chironomid ratio depending on the station (Figure 6,7). Station 7, which is immediately downstream from Boething Tree Farm had seven insects identified in the first collection of 1993; three Chironomidae, three EPT taxa, and one Megaloptera Corydalidae. The presence of Chironomids indicates that a persistent impact from Boething Tree Farm and the surrounding watershed was possible, however, since Chironomidae did not outnumber EPT taxa there was probably not a large impact at this station. Station 6, on Los Trancos Creek, had four insects in the first collection, all of which were EPT taxa. Station 5. which is immediately downstream from Portola Valley Horse Ranch had 33 insects in the first collection; including thirty EPT taxa. No impact from the Horse Ranch was detected in this collection based on the EPT/Chironomidae ratio. Land use upstream of station 4 appeared to have a slight impact based on the insect fauna. Of the nineteen insects collected eleven were Chironomidae and eight EPT taxa. At station 3, faunal composition indicated a degree of recovery from upstream impacts. EPT taxa represented $98 \%$ of the community balance and no Chironomidae were collected. One Stonefly was also in this collection, an indication of very good stream conditions. At station 2 , immediately downstream of Stanford Golf Course, stream conditions appear to favor Chironomidae and other pollution tolerant forms of macroinvertebrates. Of the 23 insects collected, 15 were from the family Chironomidae. Other insects in this collection included Diptera Muscidae, and Trichoptera Polycentropodidae both of which have a Hilsenhoff (1988a) tolerance score of (6), indicating a relatively high tolerance to impacted conditions. At station 1, eight insects were identified in the first collection, six Chironomids and two Coengrionidae. Coengrionidae have a Hilsenhoff score of (9) and are very tolerant to impacted conditions.

In the second collection of 1993, Chironomids were absent from stations 3 through 8 , and many of the species present were EPT taxa, indicating good water quality. Stations 2 and 1 , however, showed evidence of relatively low water quality. At station 2, Chironomidae represented $42 \%$ of the insect population and outnumbered EPT taxa 11 to 2. Coengrionidae were also prevalent in this collection. At station 1 a total of seven insects were collected, 6 Chironomids and 1 Limnophilidae.

Considering the two collections together in 1993, the distribution of EPT/Chironomids was fairly even at stations 3 through 8 in San Francisquito Creek 
indicating good water quality. At stations 2 and 1, however, the abundance of Chironomidae appears to indicate that stream conditions exclude some of the less tolerant forms of macroinvertebrates. The reduced stream discharge, increases in stream temperature, and possibly a concentration of unidentified pollutants from the watershed are probably the reason for the decreases in sensitive species. Chironomidae outnumbered EPT taxa more than three to one at both stations.

In 1994, the EPT/Chironomidae ratio could not be evaluated, since only six Chironomidae were collected (two at station 1, and four at station 7, collection 2) in that year. EPT taxa represented 22\% of the insects collected in 1994 compared to 67\% in 1993. The drop in the percentage of EPT taxa is probably due to large numbers of Simulidae skewing the abundance data, rather than a substantial decrease in stream water quality from the previous year.

The absence of Chironomidae in 1994 may be related to spring fluctuations in discharge or other factors associated with the early sampling, including, the life cycle characteristics of this family. In the study by Gower and Buckland (1978) on Moat Brook. Staffordshire, England, the Chironomid Riparius was found to depend on water temperature for hatching and development. The first adults emerged after 28 days at $640 \mathrm{~F}$, 36 days at $59^{\circ} \mathrm{F}$, and 49 days at $53^{\circ} \mathrm{F}$. In their study all stages of the life cycle were present from June to October after which no egg masses were found. There was a decline in larvae from December to May.

Based on previous studies (Davies 1971; Gower and Buckland 1978), it appears that Chironomidae in San Francisquito Creek probably begin hatching in late April or early May and emerge in about thirty days. In 1993, sampling began in June and ended in September at most stations. Because of the time of year, water temperature was warmer and Chironomidae were far enough along in their life cycle to be detected on the substrates. In 1994, sampling began in April, probably before hatching had occurred and ended in June, when early instar larvae, if present, were difficult to detect on the substrates.

\section{Stream Discharge 1993 vs. 1994}

Fluctuations in stream discharge influence a wide range of physical variables affecting stream biota, including nutrient, organic and sediment transport (Wallace et al. 1982, Tate and Meyer 1983), production processes at lower trophic levels (Fisher et al. 
1982), habitat availability (Schlosser 1982, Schlosser and Toth 1984, Reice 1985), and the three dimensional characteristics of the stream channel (Leopold et al. 1964).

Feminella and Resh (1990), observed in their study of Big Sulphur Creek, that disturbance occurred when peak discharge exceeded 135 times that of summer base flow levels. This criterion was based on field observations in which a single storm of that magnitude reduced larval abundance by approximately $50 \%$. The study on Big Sulphur Creek was conducted in relatively flat and wide pools. Therefore, a stream discharge of $>200 \mathrm{cfs}$ was necessary to significantly disrupt stream substrate and remove invertebrates. San Francisquito Creek with its steeper gradients and riffle sample sites is more susceptible to substrate movement during high discharge.

On San Francisquito Creek during the first collection period, a peak discharge occurred on 25 April ( $34 \mathrm{cfs}$ ) and 7 May ( $21 \mathrm{cfs}$ ). In the second collection period, a peak discharge of $11 \mathrm{cfs}$ was recorded on 17 May. The mean discharge on the stream during the collection period was $2.8 \mathrm{cfs}$. Therefore, the April storm was 12 times the mean study flow. The May storms were 8 times and 4 times mean flow.

In the context of stream benthic communities, Resh et al. (1988a) characterized hydrologic disturbance as having a frequency (i.e., a discrete recurrence interval, such as number of floods) and an intensity component (i.e., a continuous magnitude, such as discharge).

Multivoltine invertebrate populations, whose abundances can rapidly return to predisturbance levels after flooding (Fisher et al. 1982; Hemphill and Cooper 1983; Sagar 1983; Molles 1985; Grimm and Fisher 1989) appear to be particularly influenced by disturbance frequency. Univoltine populations, however, have no immediate source of recruitment after a disturbance (Resh 1982), unless undisturbed refugia are present in terrestrial (e.g., refuge for adults) or hyporheic habitats (e.g., refuge for eggs, larvae, or pupae). For these populations, parameters reflecting disturbance frequency may be expected to have less influence on density variation than those parameters that reflect disturbance intensity. This was the case for univoltine Trichopterans; Hydropsychidae, and Limnophilidae in San Francisquito Creek. In 1993, these two families represented $41 \%$ of the invertebrates collected. In 1994, they represented $6 \%$ of the population, of which $4 \%$ were collected at station 8 where peak discharges are regulated by Searsville Dam. Furthermore, short lived adults of Hydropsychidae, and Limnophilidae are not present during the time of year in which storms occur, and this population has no burrowing component (Resh et al. 1984) that can repopulate denuded stream substrata. 
In 1993, stream flow was more persistent due to the greater rainfall and associated discharge that occurred in the 1993 water year between October 1992 and April 1993. Only 0.51 inches of rainfall occurred between April and September of 1993. Therefore, base flow occurred during and prior to the sampling period beginning in June and ending in September.

In 1994, sampling began in April and by June discharge had decreased well below those discharges observed the previous year in the month of June. However storms occurred during the sampling period. The result of the fluctuating flow (storms followed by small base flow) was pronounced differences in the stream environment between sampling regimes. This may partially explain the lack in similarity of the macroinvertebrate collections.

\section{Invertebrate Production versus Chemical Parameters}

The concentrations of dissolved oxygen observed in San Francisquito Creek during the study in 1993 and 1994 were never seriously depleted. The lowest measurement (6.0 ppm) occurred at station 8 in 1993 on 29 August and 4 September. The $6.0 \mathrm{ppm}$ measurement translated to $68 \%$ saturation and, therefore, was never in the critical range to affect aquatic organisms at least during the day when measurements took place.

In 1994, levels of dissolved oxygen were higher (mean of $10.3 \mathrm{ppm}$ ) and stream temperatures were lower (mean of $64.8^{\circ} \mathrm{F}$ ) than those recorded in 1993, a result of the early spring study period. During the late summer study period in 1993 the stream was warmer with lower dissolved oxygen, but never in the critical range of $5.0 \mathrm{pp}$. or lower.

In 1994, water quality measurements were intensified. Measurements for $\mathrm{pH}$, turbidity, conductivity, and nitrites, nitrates, and ammonia yielded values that could not be considered influential to the invertebrate community.

The correlation between mean nitrate per station and 1994 abundance $(r=-0.68)$ indicated that as nitrates increased abundance decreased. This negative correlation is due primarily to high numbers of Simulidae at station 7 in the first collection of 1994, and the lower nitrate levels at stations 7 and 8 . The correlation for richness $(r=0.74)$ indicated that as nitrates increased richness increased. This may indicate that as nitrates increased the availability of high quality food increased for a variety of species. There was no correlation between abundance or richness and the concentration of phosphate or ammonia. 


\section{CHAPTER 5 CONCLUSIONS}

It is evident from this study that land use in the watershed has produced few detectable impacts to San Francisquito Creek. Sensitive forms of macroinvertebrates were present at all stations; however, they were most abundant at stations 3-8. Sensitive forms of invertebrates were rare at stations 1 and 2 , while Chironomidae was abundant. The shift in intolerant to tolerant species from upstream stations to stations 1 and 2 is probably related to higher downstream water temperature and accumulation of pollutants from the watershed. Stations 1 and 2 continually exhibited higher mean temperatures than up-stream stations, and most families of EPT taxa are sensitive to temperatures above $75^{\circ} \mathrm{F}$.

Nutrient levels found in this study were probably not detrimental to aquatic life. In fact, the level of nutrients observed may have enhanced habitat suitability by promoting instream plant growth. However, pollutants such as heavy metals and pesticides, which were not assessed may have been an additional impact at the downstream stations. The creek receives runoff from both Stanford Golf Course and Alpine Road, and must assimilate all pollutants received from up-stream land use activities.

It appears that the most significant impact to San Francisquito Creek during the study was fluctuations in stream discharge. In 1993 stream discharge was constant at the majority of the stations throughout the late summer study period, and abundance was relatively stable throughout the year. In 1994, large increases in discharge were witnessed, followed by very low stream flow, and abundance fluctuated widely between collection periods. Schlosser and Ebel (1989) found that total abundance under low flow conditions stabilized after 6-8 d, while insect abundance under elevated flow was still increasing after 16-24 d. McElravy et al. (1989) observed in their study, that insect abundance was greatest in normal or slightly above normal rainfall years, and that insect abundance declined in either drought years or very heavy discharge years. 


\section{Recommendations}

San Francisquito Creek will always have discharges that fluctuate seasonally and from year to year. However, the large fluctuations followed by low summer discharge could be minimized if water diversions were limited and more water was allowed to pass through the system.

During the study, sedimentation was not measured, but may have had a significant impact in the stream in 1994 . Portions of the stream where erosion is occurring should be planted with vegetation or some other method of erosion control. Construction in the watershed should be closely monitored to ensure the stream is not receiving pollutants or large amounts of sediment. In no way should road building or other construction be permitted to occur adjacent to the stream channel or within the riparian zone. A minimum 100 -foot buffer should be adopted for the stream where riparian vegetation is left intact (Budd et al. 1987). Street cleaning on a regular basis should be conducted by the City of Palo Alto and on any street that drains into the stream. Runoff from streets has been identified as a major source of non-point source pollution in streams.

The administrators at Stanford Golf Course should be informed of the importance of San Francisquito Creek and the wildlife that relies on this valuable resource. They should be encouraged to use natural means of pest control on the golf course, where it borders the stream. Finally, education is the key to maintaining the stream for future generations. All citizens bordering the stream should know the importance of this resource, and how they can have such a large impact on its health or lack thereof. They should reduce fertilizer and pesticide use, reduce irrigation runoff, and prevent spills down storm drains.

\section{Volunteers and Aquatic Insect Studies}

A major goal of this thesis was to determine the applicability of using volunteers to carry out similar macroinvertebrate studies in Santa Clara County. Most of the methods used in this study could be performed by a trained volunteer. Measurement of dissolved oxygen was very easy with the Lamotte dissolve oxygen kit, but should be performed at sunrise and sunset to detect minimal DO levels. Maximum/Minimum water temperature using the in-stream thermometers worked well. However, the thermometers should be 
secured to the stream bottom with weights to avoid loss. Estimating size and percentage of substrate takes practice, but can be learned easily. It should be noted that the field data sheets adapted from Rapid Bioassessment Protocols (EPA 1989) were extremely valuable in assessing the abiotic parameters of the stream. Water quality testing did not yield results that indicated organic pollution as impacting aquatic insects severely. These tests are also very expensive to send out for analysis. It may be more feasible to use field measurements for many of the organic pollutants as described by Rigney (1993), or do specialized testing when conditions seem to warrant it, such as, spills, big storms, or near-by construction.

The collection of invertebrates utilizing artificial substrates appears to be a good method, for volunteers. The investigator simply has to place the substrate in the stream and return in six weeks for collection. However, some precautions should be taken: avoid stream sections that have severely decreased flows or non-existent flows; avoid areas of the stream that are well traveled because theft is always a factor, and data can be lost. Insect data are extremely sensitive to seasonal timing of sampling. Sampling regimes that begin too early in the year can be impacted by fluctuations in stream discharge. Sampling should probably begin in May in Santa Clara County. An experienced biologist should be consulted for site suitability, time of year, placement of substrates, and interpretation of results.

Identification may be the most difficult portion of the study. The process is very tedious and time consuming, and only the most dedicated volunteer should attempt identification. A dissecting microscope is a necessity, as is a good taxonomic key. Accurate identification is extremely important and practice will be necessary. However, I became quite good at identifying insects after a relatively short time, and most aquatic insects of importance can be learned and identified with proper instruction.

Finally, it is my opinion that benthic macroinvertebrate studies in Santa Clara County are worth the substantial effort that is involved. If only water quality testing were performed in this study, important factors affecting the aquatic environment, such as fluctuations in discharge and stream water temperature would probably have been missed.

This study has shown that, while there are impacts to the system that reduce habitat suitability, San Francisquito Creek is generally a very good aquatic habitat.

A concerted effort by well supervised volunteers to assess county creeks will add to our knowledge about creek conditions in general. This data will allow creeks to be rated by quality and provide direction for creek restoration efforts. Ultimately, a County wide volunteer macroinvertebrate study will provide baseline data and an inventory of existing 
species and conditions, which can be used to assess future impacts to our creeks from increasing human land uses. 


\section{$\underline{\text { Literature Cited }}$}

Ancher, M. 1976. An analysis of the nitrate and phosphate content of the San Francisquito Creek. Stanford University, Jasper Ridge Papers.

Anderson, N. H., and Kenneth W. Cummins. 1979. Influences of Diet on the Life Histories of Aquatic Insects. Journal of the Fisheries Resource Board. Canada 36: 335-341.

Aston, R. J. 1973. Short term effects of highway construction on the limnology of a small stream in southern Ontario. Freshwater Biology 7: 99-108.

Bane, C. A., and O. T. Lind. 1978. The benthic invertebrates standing crop and diversity of a small desert stream in the Big Bend National Park, Texas. Southwestern Naturalist 23: 215-226.

Brinkhurst, R. O. 1965. Observations on the recovery of a British river from gross organic pollution. Hydrobiologia 25: 9-51.

Brooker, M. P. and R. J. Hemsworth. 1978. The effect of the release of an artificial discharge of water on invertebrate drift in the River Wye, Wales. Hydrobiologia 59: 155-163.

Budd, W. W., P. L. Cohen, P. R. Saunders, F. R. Steiner. 1987. Stream corridor management in the Pacific Northwest: I. Determination of stream corridor widths. Environmental Management 11: 587-597.

Butcher, R. W. 1955. Relation between biology and the polluted condition of the Trent. Verhandlungen Internationale Verinigung fur Theoretische und Angewandte Limnologie 12: 823-827.

Cairns, J., Jr. and K. L. Dickson. 1971. A simple method for biological assessment of the effects of waste discharge on aquatic bottom dwelling organisms. Journal of the Water Pollution Control Federation 43: 755-772.

Chutter, F. M. 1972. An empirical biotic index of the quality of water in South African streams and rivers. Water Research 6: 19-30.

Cole, Gerald A. 1983. Textbook of Limnology. Illinois: Waveland Press.

Cummins, K.W. 1974. Structure and Function of stream Ecosystems. BioScience 24: 631-641. 
1975. The ecology of running waters: theory and practice. In proceedings of the Sanduskv River Basin Symposium. International Joint Commission on the Great Lakes. Heidelberg College, Tiffin, Ohio, USA. 277293.

Davies, L. J. 1971. Some factors influencing the distribution of macroinvertebrates in the riffles of organically polluted streams. Ph. D. diss., University of Aston in Birmingham.

Duff, J. H. 1987. Nitrate reduction associated with epilithic algal communities. M. S. diss., San Frarcisco State University.

Eaton, L. E., D. Lenat. 1991. Comparison of a rapid bioassessment method with North Carolina's qualitative macroinvertebrate collection method. Joumal of the North American Benthological Society 10: 335-338.

Egglishaw, H. J. 1964. The distributional relationship between the bottom fauna and plant detritus in streams. Journal of Animal Ecology 33: 463-476.

E.P.A. 1989. Rapid Bioassessment Protocols for use in Streams and Rivers: Benthic Macroinvertebrates and Fish. Environmental Research Laboratory, Office of Research and Development, USEPA. EPA/444/4-89-001.

Extence, C. A. 1981. The effect of drought on benthic invertebrate communities in a lowland river. Hvdrobiologia 83: 217-224.

Feminella, J. W., and Vincent H. Resh. 1990. Hydrologic influences, disturbance, and intraspecific competition in a stream caddisfly population. Ecologv 71: 20832094.

Ferrington, L. C. 1987. Collection and Identification of Floating Exuviae of Chironomidae for Use in Studies of Surface Water Quality SOP No. FW 130 A. U.S. EPA. Region VII. Kansas City, Kansas.

Field, R., 1975. Coping with urban runoff in the U. S. A. Water Research 9: 499-506.

Fisher, S. G., J. Gray, N. B. Grimm, and D. E. Busch. 1982. Temporal succession in a desert stream ecosystem following flash flooding. Ecological Monographs 52: 93110 .

and G. E. Likens. 1973. Energy flow in Bear Brook, New Hampshire: an integrative approach to stream ecosystem metabolism. Ecological Monographs 43: $421-439$.

Gore, J. A. 1985. Mechanisms of colonization and habitat enhancement for benthic macroinvertebrates in restored river channels. In The restoration of rivers and streams, ed. J. A. Gore, 81-101. Boston: Butterworth Publishers. 
Gower, A.M., and P. J. Buckland. 1978. Water quality and the presence of Chironomus riparius (Diptera:Chironomidae) in a stream receiving sewage effluent. Freshwater Biology 8: 153-164.

Grimm, N. B., and S. G. Fisher. 1989. Stability of periphyton and macroinvertebrates to disturbance by flash floods in a desert stream. Journal of North American Benthological Society 8: 293-307.

Hall, C. A. S. 1972. Migration and Metabolism in a temperate stream ecosystem. Ecologv 53: 585-604.

Harms, L. L., J. N. Dornbush, and J. R. Anderson. 1974. Physical and chemical quality of agricultural land runoff. Journal of the Water Pollution Control Federation 46: 1795.

Hawkes, H.A., and L. J. Davies. 1970. Some effects of organic enrichment on benthic invertebrate communities in stream riffles. In The Scientific Management of Plant and Animal Communities for Conservation, ed. E. Duffey and A. S. Watt, British Ecological Society Symposium 11: 271-293.

Heiman, D. R., and A. W. Knight. 1975. The influence of temperature on the bioenergetics of the carnivorous stonefly nymph. Acroneuria califomica (Plecoptera: Perlidae) Ecology 56: 105-116.

Hemphill, N., and S. D. Cooper. 1983. The effect of physical disturbance on the relative abundance of two filter-feeding insects in a small stream. Oecologia (Berlin) 58: 378-382.

Hilsenhoff, W. L. 1977. Use of arthropods to evaluate water quality of streams. Technical Bulletin: Wisconsin Department of Natural Resources. 100. 15pp.

1987. An improved biotic index of organic stream pollution. Great Lakes Entomologist 20: 31-39.

1988a. Rapid field assessment of organic pollution with a family level biotic index. Journal of the North American Benthological Societv. 7: 9-13.

Hynes, H. B. N. 1958. The effect of drought on the fauna of a small mountain stream in Wales. Verhandlungen der Internationalen Vereinigung fur Theoretische und Angewandte Limnologie 13: 826-833.

1960. The Biology of Polluted Waters. Liverpool, University Press.

1961. The invertebrate fauna of a Welch mountain stream. Archives Hydrobiologia 57: 344-388.

Press.

1970. The ecology of running waters. Toronto: University of Toronto 
Iverson, T. M., P. Wilberg-Larsen, S. Birkholm Hanson, and F. S. Hansen. 1978. The effect of partial and total drought on the macroinvertebrate communities of three small Danish streams. Hydrobiologia 60: 235-242.

Kamler, E., and W. Riedel. 1960. The effect of drought on the fauna Ephemeroptera, Plecoptera, and Trichoptera of a mountain stream. Polskie Archiwum Hvdrobiologii 8: 87-94.

Larimore, R. W., W. F. Childers, and C. Heckrotte. 1959. Destruction and reestablishment of stream fish and invertebrates affected by drought. Transactions of the American Fisheries Societv 88: 261-285.

Learner, M. A., R. Williams., M. Harcup, and B. D. Huges. 1971. A survey of the macroinvertebrate fauna of the River Cynon, a polluted tributary of the River Taff (South Wales). Freshwater Biology 1: 339-347.

Lenat, D. R. 1983. Chironomid taxa richness. Natural variation and use in pollution assessment. Freshwater Invertebrate Biology 2 (April): 192-198.

1988. Water quality assessment of streams using a qualitative collection method for benthic macroinvertebrates. Journal of the North American Benthological Society 7(March): 222-233.

Leopold, L., M. G. Wolman, and J. P. Miller. 1964. Fluvial processes in geomorphologv. San Francisco: W. H. Freeman.

Lyford, J. H., and S. V. Gregory. 1975. The dynamics and structure of periphyton communities in three Cascade Mountain Streams. Verhandlungen Internationale Vereinigung fur Theoretische und Angewandte Limnologie 19: 1610-1616.

McElhone, M. J., R. W. Davies, and J. M. Culp. 1987. Factors influencing the abundance of Trichoptera in Harley Creek, a brownwater stream in northeastern Alberta, Canada. Archives fur Hydrobiolgie 109: 279-285.

McElravy, E.P. 1988. Temporal variability in abundance of aquatic insects: a comparison of temperate and tropical habitats. Ph.D. diss., University of California, Berkeley.

G. A. Lamberti, and V. H. Resh. 1989. Year-to-year variation in the aquatic invertebrate fauna of a northern California stream. Joumal of the North American Benthological Society 8(January): 51-63.

Merritt, Richard M., and Kenneth W. Cummins. 1984. An introduction to aquatic insects. $2 d$ ed. Dubuque, Iowa: Kendall-Hunt.

Minshall, G. W. 1967. Role of allochthonous detritus in the trophic structure of a woodland streambrook community. Ecology 48: 139-149.

, D. A. Andrews, F. L. Rose, R. L. Newell, and D. W. Shaw. 1972. Validation studies at Deep Creek, Curlew Valley. US/IBP Desert Biome RM 72-5 (59p). 
D. A. Andrews, F. L. Rose, R. L. Newell, and D. W. Shaw. 1973. Validation studies at Deep Creek, Curlew Valley. US/IBP Desert Biome RM $73-$ 48. (99p).

J. T. Brock, D.A. McCullough, R.W. Dunn, M. R. McSorley, and R. Pace. 1975. US/IBP Desert Biome RM 75-46. (31p).

, J. T. Brock, D.A. McCullough, R.W. Dunn, M. R. McSorley, and R. Pace. 1978. Deep Creek Studies 1975-76. US/IBP Desert Biome RM 75-46. (35p).

Moffett, J. W. 1936. A quantitative study of the bottom fauna in some Utah streams variously affected by erosion. Bulletin of the University of Utah: Biological Series 26 (September): 1-33.

Molles, M. C. 1985. Recovery of a stream invertebrate community from a flash flood in Tesuque Creek, New Mexico. Southwestern Naturalist 30: 279-287.

Mount, D. I., T. J. Norberg-King, M. T. Barbour, T. H. Roush, and W. F. Brandes. 1984. Effluent and Ambient Toxicity Testing and Instream Community Response on the Ottawa River. Lima, Ohio. Report No. EPA-600-J-84-080. USEPA. Duluth, Minnesota.

Nelson, D. J., and D. C. Scott. 1962. Role of detritus in the productivity of rock out crop community in a piedmont stream. Limnology Oceanographer 7: 396-413.

Nuttall, P. M., and J. B. Purves. 1974. Numerical indices applied to the results of a survey of the macroinvertebrate fauna of the Tamar catchment (Southwest England). Freshwater Biology 4: 213-222.

Paine, G. H., and A. R. Gaufin. 1956. Aquatic Diptera as indicators of pollution in a midwestern stream. Ohio Journal of Science 56: 291-304.

Pantle, R., and H. Buck. 1955. Die biologische Uberwachund der Gewasser und die Darstellung der Ergebnisse. Gas und Wasserfach 96: 604.

Pearson, R. G. 1984. Temporal changes in the composition and abundance of the macroinvertebrate communities of the River Hull. Archives fur Hydrobiologie 100: 273298.

Pitcairn, C. E. R., and H. A. Hawkes. 1973. The role of phosphorous in the growth of Cladophora. Water Resources 7: 159-71.

Reice, S. R. 1985. Experimental disturbance and the maintenance of species diversity in a stream community. Oecologia (Berlin) 67: 90-97.

Resh, V. H. 1982. Age structure alteration in a caddisfly population after habitat loss and recovery. Oikos 38: 280-284. 
G. A. Lamberti, E. P. McElravy, J. R. Wood, and J.W. Feminella. 1984. Quantitative methods for evaluating the effects of geothermal energy development on stream benthic communities at The Geysers, California. California Water Resources Center Contribution No. 190. California Water Resources Center. University. of California, Davis, Ca.

, A. V. Brown, A. P. Covich, M. E. Gurtz, H. W. Li, G. W. Minshall, S. R. Reice, A. L. Sheldon, J. B. Wallace, and R. Wissmar. 1988a. The role of disturbance in stream ecology. Joumal of the North American Benthological Society 7: 433-455.

, and J. K. Jackson. 1993. Rapid Assessment Approaches to Biomonitoring

Using Benthic Macroinvertebrates. In Freshwater Biomonitoring and Benthic Macroinvertebrates, ed. David M. Rosenberg and Vincent H. Resh, 195-233. New York, London: Chapman and Hall.

Professor of Entomological Sciences at the University of California, Berkeley. 1994. Interview by author. Berkeley, Ca.

Rigney, Theresa E. 1993. Citizens water quality monitoring of urban creeks. M. S. diss., University of San Francisco.

Sager, P. M. 1983. Invertebrate recolonisation of previously dry channels in the Rakaia River. New Zealand Journal of Marine and Freshwater Research 17: 377-386.

1986. The effect of floods on the invertebrate fauna of a large, unstable braided river. New Zealand Journal of Marine and Freshwater Research 20: 37 46.

Schindler, D.W. 1968. Feeding, assimilation, and respiration rates of Daphnia magna under various environmental conditions and their relation to production estimates. Journal of Animal Ecology 37: 369-385.

Schlosser, I. J. 1982. Fish community structure and function along two habitat gradients in a headwater stream. Ecological Monographs 52: 395-414.

and L. A. Toth. 1984. Niche relationships and population ecology of rainbow (Etheostoma caeruleum) and fantail (E. Flabellare) darters in a temporally variable environment. Oikos 42: 229-238.

, and K. K. Ebel. 1989. Effects of flow regime and cyprinid predation on a headwater stream. Ecological Monographs 59 (January): 41-57.

Scullion, J., and A. Sinton. 1983. Effects of artificial freshets on substratum composition, benthic invertebrate fauna and invertebrate drift in two impounded rivers in mid-Wales. Hydrobiologia 7: 261 -269.

Sheldon, A.L. 1969. Size relationships of Acroneuria california (Perlidae, Plecoptera) and its prey. Hydrobiologia 34: 85-94. 
Siegfried, J., and A. W. Knight. 1977. The effects of washout in a Sierra foothill stream. American Midland Naturalist 98: 200-207.

Sokol, D. 1963. "The hydrogeology of the San Francisquito Creek basin, San Mateo and Santa Clara Counties, California. Ph. D. diss., Stanford University, Palo Alto,
California.

Smith, Jerry, Professor of biological sciences at San Jose State University. 1993. Interview by author. San Jose State University.

Stanford University, Department of Biological Sciences 1989. Stream survey in San Francisquito and Los Trancos Creeks, Stanford University, Jasper Ridge Papers.

Surber, E. W. 1953. Biological effects of pollution in Michigan waters. Sewage and Industrial Wastes 25: 79-86.

Suberkropp, K., and M. J. Klug. 1976. Fungi and bacteria associated with leaves during processing in a woodland stream. Ecologv 67: 246-255.

Tate, C. M., and J. L. Meyer. 1983. The influence of hydrologic conditions and successional state on dissolved organic export from forested watersheds. Ecology
64: $25-32$.

Teal, J. M. 1957. Community metabolism in a temperate cold spring. Ecological Monogram 27: 283-302.

Thorup, J. 1970. The influence of a short-termed flood on a springbrook community. Archives fur Hydrobiologie 66: 447-457.

Tiller, D. 1993. Analysis and interpretation of benthic macroinvertebrate surveys. In Freshwater Biomonitoring and Benthic Macroinvertebrates, ed. David M. Rosenberg and Vincent $\mathrm{H}$. Resh, 234-286. New York, London: Chapman and
Hall. Tilly, L. J. 1968. The structure and dynamics of a cone spring. Ecological Monogram
38: 169-197.

Vannote, R.L. 1977. The river continuum: A theoretical construct for analvsis of river ecosystems. Unpubl. Typescript. (42p).

Vannote, R. L., G.W. Minshall, K. W. Cummins, J. R. Sedell, and C.E. Cushing. 1980. The river continuum concept. Canadian Journal of Fisheries and Aquatic Science
37: 130-137.

Wallace, D.A., and R. R. Daque. 1973. Modeling of land runoff effects on dissolved oxygen. Journal of the Water Pollution Control Federation 45: 1795.

Wallace, B. J., D. H. Ross, and J. L. Meyer. 1982. Seston and dissolved organic carbon dynamics in a southern Appalachian stream. Ecology 63: 824-838. 
Wanielista, M. P. 1976. Nonpoint source effects. Technological University Press: Orlando, Florida.

Y. A. Yousef, and W. M. Mclelleon. 1977. Nonpoint source effects on water quality. Journal of the Water Pollution Control Federation 36: 441-451.

Washington, H. G. 1984. Diversity, biotic and similarity indices. A review with special reference to aquatic ecosystems. Water Research 18:653-94.

Weibel, S. R., R. B. Weidner, J. M. Cohen, and A. G. Christianson. 1966. Pesticides and other contaminants in rainfall and runoff as a factor in stream pollution. Journal of the Water Pollution Control Federation 36: 914-924.

Whitely, L. S. 1968. The resistance of tubificid worms to three common pollutants. Hydrobiologia 32: 1075-1084.

Whiting, E. R., and H. F. Clifford. 1983. Invertebrates and urban runoff in a small northern stream, Edmonton, Alberta, Canada. Hydrobiologia 102: 73-80.

Whitton, B. A. 1970. Biology of Cladophora in freshwater. Water Resources 4: 457-76.

Williams, D. D., and H. B. N. Hynes. 1977. The ecology of temporary streams. II. General remarks on temporary streams. Internationale Revue der gesamten Hvdrobiologie 62: 53-61.

Winner, R. W., M.W. Boesel, and M.P. Farrell. 1980. Insect community structure as an index of heavy-metal pollution in lotic ecosystems. Canadian Journal of Fisheries and Aquatic Science 37: 647-655. 


\title{
APPENDIX A
}

\section{TOLERANCE VALUES FOR FAMILIES OF STREAM ARTHROPODS IN THE} GREAT LAKES REGION, U.S.A. (E.P.A. 1989, Appendix C)

\author{
ORDER $\quad$ FAMLIES \\ Plecoptera Capniidae 1, Cloroperlidae 1, Leutridae 0, Nemouridae 2, Perlidae \\ 1, Perlodidae 2, Pteronarcyidae 0, Taeniopterygidae 2 \\ Ephemeroptera Baetidae 4, Baetiscidae 3, Caenidae 7, Ephemerellidae 1, \\ Ephemeridae 4, Heptageniidae 4, Leptophlebiidae 2, Metretopodidae \\ 2, Oligoneuriidae 2, Polymitarcyidae 2, Potomanthidae 4, \\ Siphlonuridae 7 , Tricorythidae 4 \\ Odonata \\ Aeshnidae 3, Caopterygidae 5, Coenagrionidae 9, Cordulegastridae \\ 3, Cordulidae 5, Gomphidae 1, Lestidae 9, Libellulidae 9, \\ Macromiidae 3 \\ Trichoptera \\ Brachycentridae 1, Glossossomatidae 0, Helicopsychidae 3, \\ Hydropsychidae 4, Hydroptilidae 4, Lepidostomatidae 1, \\ Leptoceridae 4, Limnephilidae 4, Molannidae 6, Odontoceridae 0, \\ Philopotamidae 3, Phryganeidae 4, Polycentropodidae 6 \\ Psychomyiidae 2, Rhyacophilidae 0, Sericostomatidae 3 \\ Megaloptera $\quad$ Corydalidae 0, Sialidae 4 \\ Lepidoptera Pyralidae 5 \\ Coleoptera Dryopidae 5, Elmidae 4, Psephenidae 4
}


ORDER

Diptera

\section{FAMMLIES}

Athericidae 2, Blephariceridae 0, Ceretopogonidae 6, Blood-red Chironomidae (Chironomini) 8, other (including pink) Chironomidae 6, Dolochopodidae 4, Emphidae 6, Ephydridae 6, Psychodidae 10, Simulidae 6, Muscidae 6, Syrphidae, 10, Tabanidae 6, Tipulidae 3 


\section{APPENDIX B \\ PHYSICAL CHARACTERISTICS RECORDED ON FIELD DATA SHEETS FOR STATIONS 1-8, CONDUCTED IN MAY 1993 \\ PHYSICAL CHARACTERISTICS/WATER QUALITY \\ FIELD DATA SHEET \\ STATION \#1}

\section{PHYSICAL CHARATERISTICS}

\section{RIPARIAN ZONE/INSTREAM FEATURES}

Predominent Surrounding Land Use:

Forest Field/Pasture Agricultural Residential Commercial Industrial OtherLocal Watershed Erosion: Some Moderate Heavy

Local Watershed NPS Pollution:No Evidence Some Potential Source Obvious

Sources

Estimated Stream Width $15 \mathrm{~m} \quad$ Estimated Stream Depth: Riffle $\underline{10}$

High Water Mark 2 m Dam Present: Yes_ No X_Channelized: Yes_ No X

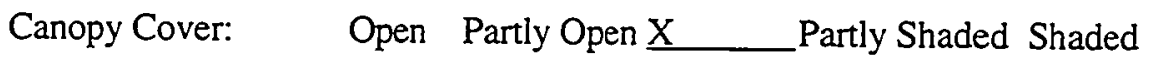

SEDIMENT/SUBSTRATE:

Sediment Odors: Normal $\underline{X}$ Sewege Chemical Anaerobic None

Other

Sediment Oils: Absent $\underline{X}$ Slight Moderate Profuse

Sediment Deposits: Sludge Sawdust Detritus $\underline{\mathrm{X} \text { Shells }}$

Other

Algae Present: Filamentous algae present

Are the undersides of deeply embeddded stones black? Yes No $\underline{X}$

Inorganic Sustrate Characteristic

\begin{tabular}{|c|c|c|}
\hline Substrate Type & Diameter & Percent Compositon \\
\hline Boulder & $>256 \mathrm{~mm}(10 \mathrm{in})$. & \\
\hline Cobble & $64-256 \mathrm{~mm}$ & $70 \%$ \\
\hline Gravel & $2-64 \mathrm{~mm}$ & \\
\hline Sand & $0.06-2.00 \mathrm{~mm}$ & $10 \%$ \\
\hline$\underline{\text { Silt }}$ & $0.004-.06 \mathrm{~mm}$ & $15 \%$ \\
\hline Clay & $<0.004$ slick & $5 \%$ \\
\hline
\end{tabular}




\section{PHYSICAL CHARACTERISTICS/WATER QUALITY FIELD DATA SHEET \\ STATION \#2}

\section{PHYSICAL CHARATERISTICS}

\section{RIPARIAN ZONE/INSTREAM FEATURES}

Predominent Surrounding Land Use:

Forest Field/Pasture Agricultural Residential Commercial Industrial OtherLocal Watershed Erosion: Some Moderate Heavy

Local Watershed NPS Pollution:No Evidence Some Potential Source Obvious Sources

Estimated Stream Width $11 \mathrm{~m} \quad$ Estimated Stream Depth: Riffle $.17 \mathrm{~m}$

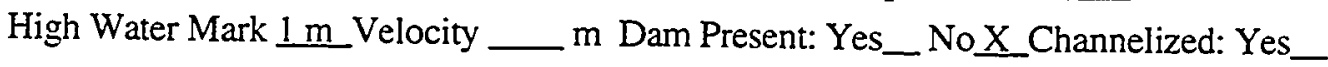
NoX

Canopy Cover: Open Partly Open X_Partly Shaded Shaded SEDIMENT/SUBSTRATE:

Sediment Odors: Normal $\underline{X}$ Sewege Chemical Anaerobic None Other

Sediment Oils: Absent $\underline{X \quad \text { Slight } \quad \text { Moderate Profuse }}$

Sediment Deposits: Sludge Sawdust Detritus $\underline{X \quad \text { Shells }}$ Other

Algae Present: Extensive growths of filamentous algae

Are the undersides of deeply embeddded stones black? Yes No $\underline{X}$

Inorganic Sustrate Characteristic

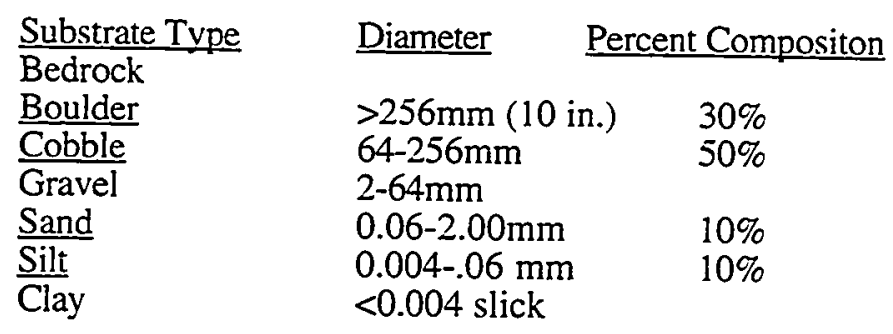




\section{PHYSICAL CHARACTERISTICS/WATER QUALITY FIELD DATA SHEET \\ STATION \#3}

\section{PHYSICAL CHARATERISTICS}

RIPARIAN ZONE/INSTREAM FEATURES

Predominent Surrounding Land Use:

Forest Field/Pasture Agricultural Residential Commercial Industrial Other-

Local Watershed Erosion: Some Moderate Heavy

Local Watershed NPS Pollution: No Evidence Some Potential Source Obvious

Sources

Estimated Stream Width $15 \mathrm{~m} \quad$ Estimated Stream Depth: Riffle $10 \mathrm{~m}$

High Water Mark 2 m Dam Present: Yes_ No X_Channelized: Yes_ No $\underline{X}$

Canopy Cover: Open Partly Open Partly Shaded Shaded

SEDIMENT/SUBSTRATE:

Sediment Odors: Normal Sewege Chemical Anaerobic None Other

Sediment Oils: Absent Slight Moderate Profuse

Sediment Deposits: Sludge Sawdust Detritus Shells

Other

Algae Present: Filamentous algae and chlorophyll $a$

Are the undersides of deeply embeddded stones black? Yes No $\underline{\mathrm{X}}$

Inorganic Sustrate Characteristic

\begin{tabular}{llll} 
Substrate Type & & Diameter & Percent Compositon \\
\hline Bedrock & & & \\
Boulder & & $256 \mathrm{~mm}(10 \mathrm{in})$. & $25 \%$ \\
Cobble & & $64-256 \mathrm{~mm}$ & $50 \%$ \\
Gravel & $2-64 \mathrm{~mm}$ & \\
Sand & $0.06-2.00 \mathrm{~mm}$ & $20 \%$ \\
Silt & $0.004-.06 \mathrm{~mm}$ & $5 \%$ \\
Clay & $<0.004 \mathrm{slick}$ &
\end{tabular}




\section{PHYSICAL CHARACTERISTICS/WATER QUALITY FIELD DATA SHEET \\ STATION \#4}

\section{PHYSICAL CHARATERISTICS}

\section{RIPARIAN ZONE/INSTREAM FEATURES}

Predominent Surrounding Land Use:

Forest Field/Pasture Agricultural Residential Commercial Industrial OtherLocal Watershed Erosion: Some Moderate Heavy

Local Watershed NPS Pollution: No Evidence Some Potential Source Obvious Sources

Estimated Stream Width $5 \mathrm{~m}$ Estimated Stream Depth: Riffle $.12 \mathrm{~m}$

High Water Mark 2 m Velocity _ _ m Dam Present: Yes_ No X_Channelized: Yes_ No $\mathrm{X}$

Canopy Cover: Open Partly Open Partly Shaded Shaded

SEDIMENT/SUBSTRATE:

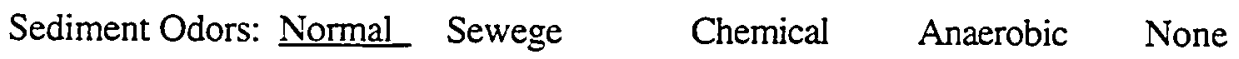
Other

Sediment Oils: $\quad$ Absent $\quad$ Slight $\quad$ Moderate Profuse

Sediment Deposits: Sludge Sawdust Detritus Shells Other

Algae Present: Filamentous algae present

Are the undersides of deeply embeddded stones black? Yes No $\underline{X}$

Inorganic Sustrate Characteristic

\begin{tabular}{|c|c|c|}
\hline Substrate Type & Diameter & It Compositon \\
\hline $\begin{array}{l}\text { Boulder } \\
\text { Cobble }\end{array}$ & $\begin{array}{l}>256 \mathrm{~mm} \text { (10 in.) } \\
64-256 \mathrm{~mm}\end{array}$ & $\begin{array}{l}30 \% \\
50 \%\end{array}$ \\
\hline $\begin{array}{l}\text { Gravel } \\
\text { Sand } \\
\text { Silt } \\
\text { Clay }\end{array}$ & $\begin{array}{l}2-64 \mathrm{~mm} \\
0.06-2.00 \mathrm{~mm} \\
0.004-.06 \mathrm{~mm} \\
<0.004 \text { slick }\end{array}$ & $\begin{array}{l}10 \% \\
10 \%\end{array}$ \\
\hline
\end{tabular}




\section{PHYSICAL CHARACTERISTICS/WATER QUALITY FIELD DATA SHEET \\ STATION \#5}

\section{PHYSICAL CHARATERISTICS}

\section{RIPARIAN ZONE/INSTREAM FEATURES}

Predominent Surrounding Land Use:

Forest Field/Pasture Agricultural Residential Commercial Industrial Other-

Local Watershed Erosion: Some Moderate Heavy

Local Watershed NPS Pollution: No Evidence Some Potential Source Obvious

Sources

Estimated Stream Width $14 \mathrm{~m} \quad$ Estimated Stream Depth: Riffle $.15 \mathrm{~m}$

High Water Mark $2.0 \mathrm{~m}$ Dam Present: Yes_No__ Channelized: Yes_No $\underline{X}$

Canopy Cover: Open Partly Open Partly Shaded Shaded

SEDIMENT/SUBSTRATE:

Sediment Odors: Normal Sewege Chemical Anaerobic None

Other

Sediment Oils: $\quad$ Absent $\quad$ Slight $\quad$ Moderate Profuse

Sediment Deposits: Sludge Sawdust Detritus Shells Other

Algae Present: Large amounts of filamentous algae

Are the undersides of deeply embeddded stones black?Yes No $\underline{X}$

Inorganic Sustrate Characteristic

\begin{tabular}{|c|c|c|}
\hline$\frac{\text { Substrate Type }}{\text { Bedrock }}$ & Diameter & Percent Compositon \\
\hline Boulder & $>256 \mathrm{~mm}$ (10 in.) & $50 \%$ \\
\hline $\begin{array}{l}\text { Cobble } \\
\text { Gravel }\end{array}$ & $\begin{array}{l}\text { 64-256mm } \\
2-64 \mathrm{~mm}\end{array}$ & \\
\hline Sand & $0.06-2.00 \mathrm{~mm}$ & \\
\hline Silt & $0.004-.06 \mathrm{~mm}$ & $10 \%$ \\
\hline Clay & $<0.004$ slick & $10 \%$ \\
\hline
\end{tabular}




\section{PHYSICAL CHARACTERISTICS/WATER QUALITY \\ FIELD DATA SHEET \\ STATION \#6}

\section{PHYSICAL CHARATERISTICS}

\section{RIPARIAN ZONE/INSTREAM FEATURES}

Predominent Surrounding Land Use:

Forest Field/Pasture Agricultural Residential Commercial Industrial OtherLocal Watershed Erosion: Some Moderate Heavy

Local Watershed NPS Pollution: No Evidence Some Potential Source Obvious Sources

Estimated Stream Width $\underline{5 \mathrm{~m}}$ Estimated Stream Depth: Riffle $.10 \mathrm{~m}$

High Water Mark $1 \mathrm{~m}$ Dam Present: Yes_No X_Channelized: Yes_ No $\underline{X}$

Canopy Cover: Open Partly Open Partly Shaded Shaded

SEDIMENT/SUBSTRATE:

Sediment Odors: Normal Sewege Chemical Anaerobic None Other

Sediment Oils: $\quad$ Absent $\quad$ Slight Moderate Profuse

Sediment Deposits: Sludge Sawdust Detritus Shells Other:

Algae Present: Very small amounts of chlorophyll $a$ on substrate.

Are the undersides of deeply embeddded stones black? Yes No $\underline{X}$

Inorganic Sustrate Characteristic

\begin{tabular}{|c|c|c|}
\hline Substrate Tvpe & Diameter & Percent Compositon \\
\hline $\begin{array}{l}\text { Boulder } \\
\text { Cobble }\end{array}$ & $\begin{array}{l}>256 \mathrm{~mm}(10 \mathrm{in} .) \\
64-256 \mathrm{~mm}\end{array}$ & $\begin{array}{l}30 \% \\
50 \%\end{array}$ \\
\hline $\begin{array}{l}\text { Gravel } \\
\text { Sand } \\
\text { Silt } \\
\text { Clay }\end{array}$ & $\begin{array}{l}2-64 \mathrm{~mm} \\
0.06-2.00 \mathrm{~mm} \\
0.004-.06 \mathrm{~mm} \\
<0.004 \text { slick }\end{array}$ & $\begin{array}{l}10 \% \\
10 \%\end{array}$ \\
\hline
\end{tabular}




\section{PHYSICAL CHARACTERISTICS/WATER QUALITY \\ FIELD DATA SHEET \\ STATION \#7}

\section{PHYSICAL CHARATERISTICS}

\section{RIPARIAN ZONE/INSTREAM FEATURES}

Predominent Surrounding Land Use:

Forest Field/Pasture Agricultural Residential Commercial Industrial Other

Local Watershed Erosion: Some Moderate Heavy

Local Watershed NPS Pollution: No Evidence Some Potential Source Obvious

Estimated Stream Width $14 \mathrm{~m} \quad$ Estimated Stream Depth: Riffle $.09 \mathrm{~m}$

High Water Mark! m_Dam Present: Yes_ No X Channelized: Yes_ No X

Canopy Cover: Open Partly Open Partly Shaded Shaded

SEDIMENT/SUBSTRATE:

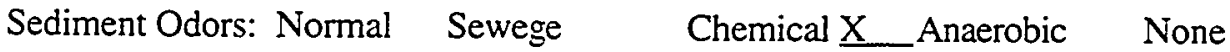

Other

Sediment Oils: $\quad$ Absent $\quad$ Slight Moderate Profuse

Sediment Deposits: Sludge Sawdust Detritus Shells Other:

Rocks appear discolored.

Algae Present: Very little, chlorvphyll a on cbbles

Are the undersides of deeply embeddded stones black? Yes No $\underline{X}$

Inorganic Sustrate Characteristic

\begin{tabular}{|c|c|c|}
\hline Substrate Type & Diameter & it Compositon \\
\hline Boulder & $>256 \mathrm{~mm}(10 \mathrm{in})$. & \\
\hline Cobble & $64-256 \mathrm{~mm}$ & $70 \%$ \\
\hline Gravel & $2-64 \mathrm{~mm}$ & $20 \%$ \\
\hline Sand & $0.06-2.00 \mathrm{~mm}$ & $10 \%$ \\
\hline Silt & $0.004-.06 \mathrm{~mm}$ & \\
\hline Clay & $<0.004$ slick & \\
\hline
\end{tabular}




\section{PHYSICAL CHARACTERISTICS/WATER QUALITY \\ FIELD DATA SHEET \\ STATION \#8}

\section{PHYSICAL CHARATERISTICS}

\section{RIPARIAN ZONE/INSTREAM FEATURES}

Predominent Surrounding Land Use:

Forest Field/Pasture Agricultural Residential Commercial Industrial Other-

Local Watershed Erosion: Some Moderate Heavy

Local Watershed NPS Pollution: No Evidence Some Potential Source Obvious

Sources

Estimated Stream Width $14 \mathrm{~m}$ Estimated Stream Depth: Riffle $.11 \mathrm{~m}$

High Water Mark $1 \mathrm{~m}$ Velocity m Dam Present: Yes X No Channelized: Yes

NoX Cover: Open Partly Open Partly Shaded Shaded

SEDIMENT/SUBSTRATE:

\begin{tabular}{|c|c|c|c|c|}
\hline $\begin{array}{c}\text { Sediment Odors: } \\
\text { Other }\end{array}$ & Normal & Chemical & Anaerobic & None \\
\hline Sediment Oils: & $\underline{\text { Absent }}$ & Slight & Moderate & Profuse \\
\hline Sediment Deposit & Sludge & Sawdust & Detritus & Shells \\
\hline
\end{tabular}

Other

Algae Present: Chlorophyll $a$

Are the undersides of deeply embeddded stones black? Yes No X

Inorganic Sustrate Characteristic

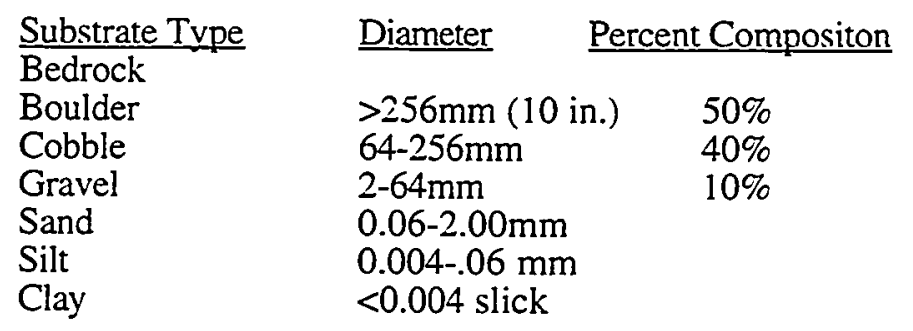




\begin{abstract}
APPENDIX C
MEASUREMENTS OF DISSOLVED OXYGEN, MAXIMUM-MINIMUM WATER

TEMPERATURE, AND STREAM DEPTH FOR SAN FRANCISQUTTO CREEK IN 1993 AND 1994
\end{abstract}

1993

STATION \#1

DATE TIME DO-ppm TEMP-MAX TEMP-MIN WATER DEPTH WATERDEPTH

SAMPLER \#1 SAMPLER \#2

$\begin{array}{rrrllll}6 / 13 / 93 & 1114 & * * & * & * * & 0.09 & 0.12 \\ 6 / 19 / 93 & 1135 & 10.2 & * * & * * & 0.09 & 0.12 \\ 6 / 26 / 93 & 930 & 7.1 & 68 & 62 & 0.11 & 0.09 \\ 7 / 3 / 93 & 950 & 7.2 & 65 & 62 & 0.11 & 0.12 \\ 7 / 10 / 93 & 850 & 6.2 & 66 & 62 & 0.11 & 0.14 \\ 7 / 17 / 93 & 1140 & 11.8 & 76 & 62 & 0.07 & 0.12 \\ 7 / 24 / 93 & 1010 & 6.8 & 80 & 62 & 0.03 & 0.05 \\ 8 / 7 / 93 & 1125 & 8.6 & 81 & 62 & 0.09 & 0.09 \\ 8 / 14 / 93 & 910 & 7.4 & 78 & 62 & 0.09 & 0.11 \\ 8 / 20 / 93 & 1305 & 11.0 & 78 & 62 & 0.08 & 0.09\end{array}$

\title{
STATION \#2
}

DATE TIME DO-ppm TEMP-MAX TEMP-MIN WATER DEPTH WATER DEPTH SAMPLER \#1 SAMPLER \#2

$\begin{array}{rrrrrrr}6 / 13 / 93 & 1300 & * * & * * & * * & 0.16 & 0.15 \\ 6 / 19 / 93 & 1225 & 8.0 & * * & * * & 0.16 & 0.14 \\ 6 / 26 / 93 & 1000 & 7.6 & 69 & 60.5 & 0.11 & 0.1 \\ 7 / 3 / 93 & 907 & 8.6 & 68 & 62 & 0.11 & 0.14 \\ 7 / 10 / 93 & 1015 & 7.8 & 65 & 64 & 0.11 & 0.11 \\ 7 / 17 / 93 & 1125 & 8.0 & 72 & 61 & 0.09 & 0.11 \\ 7 / 24 / 93 & 924 & 7.0 & 74 & 62 & 0.09 & 0.11 \\ 8 / 7 / 93 & 1105 & 8.2 & 78 & 62 & 0.09 & 0.09 \\ 8 / 14 / 93 & 925 & 7.8 & 80 & 62 & 0.09 & 0.08 \\ 8 / 20 / 93 & 1325 & 9.6 & 70 & 60 & 0.08 & 0.08 \\ 8 / 24 / 93 & 1210 & 7.4 & 72 & 64 & 0.06 & 0.07 \\ 9 / 4 / 93 & 1100 & 9.2 & 70 & 62 & 0.07 & 0.09\end{array}$


STATION \#3

DATE TIME DO-pPM TEMP-MAX TEMP-MIN WATER DEPTH WATERDEPTH

SAMPLER \#1 SAMPLER \#2

$\begin{array}{rrrllll}6 / 15 / 93 & 950 & * * & * * & * * & 0.22 & 0.15 \\ 6 / 19 / 93 & 1300 & 7.3 & * * & * * & 0.08 & 0.1 \\ 6 / 26 / 93 & 1035 & 7.8 & 69 & 60 & 0.11 & 0.08 \\ 7 / 3 / 93 & 840 & 7.2 & 62 & 60 & 0.12 & 0.09 \\ 7 / 10 / 93 & 940 & 8.6 & 68 & 65 & 0.09 & 0.09 \\ 7 / 17 / 93 & 1100 & 8.4 & 70 & 60 & 0.08 & 0.09 \\ 7 / 24 / 93 & 915 & 7.4 & 70 & 61 & 0.07 & 0.08 \\ 8 / 14 / 93 & 945 & 8.2 & 74 & 62 & 0.07 & 0.08 \\ 8 / 20 / 93 & 1345 & 9.4 & 78 & 62 & 0.07 & 0.07 \\ 8 / 24 / 93 & 1155 & 8.0 & 70 & 62 & 0.06 & 0.07 \\ 9 / 4 / 93 & 1040 & 7.2 & 70 & 62 & 0.06 & 0.06\end{array}$

STATION \#4

DATE TIME DO-ppm TEMP-MAX TEMP-MIN WATERDEPTH WATERDEPTH

SAMPLER \#1 SAMPLER \#2

$\begin{array}{rrrrrrr}6 / 15 / 93 & 1045 & * * & * * & * * & 0.15 & 0.15 \\ 6 / 19 / 93 & 1320 & 9.2 & * * & * * & 0.14 & 0.12 \\ 6 / 26 / 93 & 1116 & 8.4 & 68 & 59 & 0.12 & 0.11 \\ 7 / 3 / 93 & 800 & 7.3 & 70 & 60.5 & 0.12 & 0.12 \\ 7 / 10 / 93 & 1005 & 8.4 & 70.5 & 60 & 0.11 & 0.11 \\ 7 / 17 / 93 & 1015 & 8.8 & 70.5 & 59 & 0.11 & 0.09 \\ 7 / 24 / 93 & 1035 & 8.3 & 72 & 60 & 0.11 & 0.11 \\ 8 / 7 / 93 & 1015 & 8.6 & 72 & 60 & 0.11 & 0.09 \\ 8 / 14 / 93 & 1030 & 8.2 & 70 & 60 & 0.11 & 0.11 \\ 8 / 20 / 93 & 1400 & 11.4 & 70 & 60 & 0.11 & 0.11 \\ 8 / 24 / 93 & 1115 & 8.0 & 72 & 60 & 0.11 & 0.11 \\ 9 / 4 / 93 & 1000 & 8.2 & 70 & 61 & 0.11 & 0.09\end{array}$


STATION \#5

DATE TIME DO-ppm TEMP-MAX TEMP-MIN WATER DEPTH WATER DEPTH

SAMPLER \#1 SAMPLER \#2

$\begin{array}{rrrrrrr}6 / 15 / 93 & 1020 & * * & * * & * * & 0.15 & 0.15 \\ 6 / 19 / 93 & 1345 & 8.0 & * * & * * & 0.09 & 0.14 \\ 6 / 26 / 93 & 1126 & 7.9 & * * & * * & 0.11 & 0.13 \\ 7 / 3 / 93 & 845 & 7.3 & 61 & 60.5 & 0.09 & 0.14 \\ 7 / 10 / 93 & 1020 & 7.0 & 70 & 62 & 0.09 & 0.12 \\ 7 / 17 / 93 & 1030 & 8.3 & 70 & 60 & 0.07 & 0.09 \\ 7 / 24 / 93 & 1050 & 7.8 & 70 & 62 & 0.09 & 0.09 \\ 8 / 7 / 93 & 1030 & 8.2 & 74 & 61 & 0.09 & 0.09 \\ 8 / 14 / 93 & 1050 & 8.6 & 69 & 60 & 0.11 & 0.11 \\ 8 / 20 / 93 & 1415 & 9.0 & 68 & 60 & 0.08 & 0.09 \\ 8 / 29 / 93 & 1145 & 8.2 & 70 & 60 & 0.09 & 0.09 \\ 9 / 4 / 93 & 1020 & 7.2 & 68 & 62 & 0.08 & 0.09\end{array}$

STATION \#6

DATE TIME DO-ppm TEMP-MAX TEMP-MIN WATER DEPTH WATER DEPTH SAMPLER \#1 SAMPLER \#2

$\begin{array}{rrrrrrr}6 / 15 / 93 & 1030 & * * & * * & * * & 0.25 & 0.21 \\ 6 / 19 / 93 & 1410 & 10.5 & * * & * * & 0.17 & 0.16 \\ 6 / 26 / 93 & 1205 & 10.0 & 62 & 58 & 0.17 & 0.15 \\ 7 / 3 / 93 & 815 & 9.5 & 69 & 58.5 & 0.18 & 0.17 \\ 7 / 10 / 93 & 1030 & 9.8 & 66 & 59 & 0.17 & 0.17 \\ 7 / 17 / 93 & 1040 & 9.2 & 66 & 58 & 0.15 & 0.16 \\ 7 / 24 / 93 & 1100 & 9.1 & 67 & 59 & 0.16 & 0.15 \\ 8 / 7 / 93 & 1035 & 9.6 & 70 & 59 & 0.14 & 0.16 \\ 8 / 14 / 93 & 1040 & 10.0 & 64 & 59 & 0.15 & 0.14 \\ 8 / 20 / 93 & 1415 & 9.6 & 66 & 58 & 0.12 & 0.15 \\ 8 / 29 / 93 & 1135 & 9.2 & 68 & 59 & 0.11 & 0.12 \\ 9 / 4 / 93 & 1013 & 9.0 & 66 & 60 & 0.12 & 0.13\end{array}$


STATION \#7

DATE TIME DO-pPM TEMP-MAX TEMP-MIN WATERDEPTH WATERDEPTH SAMPLER \#1 SAMPLER \#2

$\begin{array}{rrrrrrr}6 / 30 / 93 & 1155 & * * & * * & * * & 0.11 & 0.11 \\ 7 / 3 / 93 & 720 & 7.1 & 61 & 59 & 0.11 & 0.11 \\ 7 / 10 / 93 & 1100 & 8.0 & 70 & 60.5 & 0.09 & 0.11 \\ 7 / 17 / 93 & 950 & 8.0 & 70 & 59 & 0.08 & 0.11 \\ 7 / 26 / 93 & 1135 & 6.6 & 69 & 59 & 0.07 & 0.11 \\ 8 / 7 / 93 & 935 & 7.0 & 69 & 56 & 0.06 & 0.09\end{array}$

STATION \#8

DATE TIME DO-ppm TEMP-MAX TEMP-MIN WATER DEPTH WATER DEPTH

SAMPLER \#1 SAMPLER \#2

$\begin{array}{rrrllll}8 / 29 / 93 & 1040 & 6.0 & 68 & 57 & 0.11 & 0.11 \\ 9 / 4 / 93 & 935 & 6.0 & 68 & 58 & 0.11 & 0.09 \\ 9 / 11 / 93 & 1105 & 7.2 & 68 & 58 & 0.11 & 0.11 \\ 10 / 2 / 93 & 1235 & 6.2 & 68 & 54 & 0.09 & 0.11\end{array}$


1994

STATION \#1

DATE TIME DO-ppM TEMP-MAX TEMP-MIN WATERDEPTH WATER DEPTH

SAMPLER \# 1 SAMPLER \#2

$\begin{array}{rrrrrrr}3 / 30 / 94 & 1000 & * * & * * & * * & 0.13 & 0.14 \\ 4 / 4 / 94 & 1430 & * * & 60 & 50 & 0.12 & 0.12 \\ 4 / 11 / 94 & 1130 & 9.8 & 60 & 50 & 0.12 & 0.14 \\ 4 / 22 / 94 & 1325 & 10.4 & 64 & 54 & 0.12 & 0.14 \\ 5 / 2 / 94 & 1025 & 10.0 & 62 & 54 & 0.12 & 0.12 \\ 5 / 9 / 94 & 1300 & 11.0 & 62 & 56 & 0.13 & 0.14 \\ 5 / 16 / 94 & 1255 & 10.6 & 66 & 58 & 0.13 & 0.14 \\ 5 / 23 / 94 & 1520 & 13.0 & 66 & 54 & 0.11 & 0.13 \\ 5 / 31 / 94 & 1405 & 12.0 & 70 & 55 & 0.11 & 0.11 \\ 6 / 5 / 94 & 1445 & 12.0 & 70 & 60 & 0.11 & 0.09 \\ 6 / 13 / 94 & 1455 & 12.6 & 76 & 58 & 0.11 & 0.08 \\ 6 / 20 / 94 & * * & * * & * * & * * & * * & *\end{array}$

\section{STATION \#2}

DATE TIME DO-ppm TEMP-MAX TEMP-MIN WATERDEPTH WATERDEPTH SAMPLER \#1 SAMPLER \#2

$\begin{array}{rrrllll}3 / 30 / 94 & 1030 & * * & * * & * * & 0.19 & 0.19 \\ 4 / 4 / 94 & 1400 & 8.0 & 68 & 52 & 0.19 & 0.19 \\ 4 / 11 / 94 & 1200 & 10.2 & 68 & 52 & 0.21 & 0.21 \\ 4 / 22 / 94 & 1335 & 11.0 & 68 & 54 & 0.21 & 0.21 \\ 5 / 2 / 94 & 1050 & 10.0 & 68 & 54 & 0.15 & 0.15 \\ 5 / 9 / 94 & 1315 & 11.0 & 68 & 52 & 0.24 & 0.18 \\ 5 / 16 / 94 & 1245 & 10.2 & 64 & 58 & 0.24 & 0.18 \\ 5 / 23 / 94 & 1535 & 13.0 & 62 & 54 & 0.17 & 0.18 \\ 5 / 31 / 94 & 1355 & 9.2 & 68 & 58 & 0.15 & 0.14 \\ 6 / 5 / 94 & 1440 & 11.2 & 69 & 58 & 0.15 & 0.14 \\ 6 / 13 / 94 & 1450 & 11.0 & 72 & 58 & 0.13 & 0.13 \\ 6 / 20 / 94 & * * & * * & * * & * * & * * & *\end{array}$


STATION \#3

DATE TIME DO-pPM TEMP-MAX TEMP-MIN WATER DEPTH WATERDEPTH

SAMPLER \#1 SAMPLER \#2

\begin{tabular}{|c|c|c|c|c|c|c|}
\hline $3 / 30 / 94$ & $1100^{*}$ & & \multicolumn{2}{|c|}{$*$} & 0.12 & 0.14 \\
\hline $4 / 4 / 94$ & 1340 & 10.8 & 62 & 50 & 0.12 & 0.15 \\
\hline $4 / 11 / 94$ & 1215 & 10.0 & 61 & 52 & 0.13 & 0. \\
\hline $4 / 22 / 94$ & 1340 & 10.6 & 62 & 54 & 0.13 & 0.1 \\
\hline $5 / 2 / 94$ & 1105 & 10.0 & 62 & 54 & 0.15 & .1 \\
\hline $5 / 9 / 94$ & 1340 & 12.2 & 62 & 54 & 0.21 & .1 \\
\hline $5 / 16 / 94$ & 1230 & 10.6 & 62 & 54 & 0.21 & 0.1 \\
\hline $5 / 23 / 94$ & 1555 & 13.1 & 63 & 54 & 0.14 & 0.0 \\
\hline $5 / 31 / 94$ & 1340 & 8.0 & 64 & 54 & 0.13 & 0.0 \\
\hline $6 / 5 / 94$ & 1420 & 8.4 & 67 & 58 & 0.13 & 0.0 \\
\hline $6 / 13 / 94$ & 1425 & 9.4 & 69 & 60 & 0.12 & 0.0 \\
\hline
\end{tabular}

\section{STATION \#4}

DATE TIME DO-ppm TEMP-MAX TEMP-MIN WATER DEPTH WATER DEPTH

SAMPLER \#1 SAMPLER \#2

$\begin{array}{rrrrrrr}3 / 30 / 94 & 1155 & * * & * * & * * & 0.13 & 0.13 \\ 4 / 4 / 94 & 1355 & 10.4 & 72 & 52 & 0.13 & 0.13 \\ 4 / 11 / 94 & 1245 & 12.0 & 72 & 52 & 0.15 & 0.15 \\ 4 / 22 / 94 & 1350 & 11.6 & 72 & 52 & 0.15 & 0.15 \\ 5 / 2 / 94 & 1135 & 10.2 & 70 & 54 & 0.13 & 0.12 \\ 5 / 9 / 94 & 1355 & 9.8 & 68 & 54 & 0.17 & 0.12 \\ 5 / 16 / 94 & 1200 & 9.4 & 68 & 54 & 0.17 & 0.12 \\ 5 / 23 / 94 & 1610 & 13.3 & 62 & 52 & 0.15 & 0.11 \\ 5 / 31 / 94 & 1240 & 10.0 & 68 & 58 & 0.09 & 0.08 \\ 6 / 5 / 94 & 1400 & 11.0 & 66 & 58 & 0.08 & 0.08 \\ 6 / 13 / 94 & 1455 & 10.2 & 70 & 58 & 0.08 & 0.08 \\ 6 / 20 / 94 & * & * * & * * & * * & * * & * *\end{array}$




\section{STATION \#5}

\begin{tabular}{|c|c|c|c|c|c|c|}
\hline DATE & TIME & -ppm & $A X$ & IIN & $\begin{array}{l}\text { EEPTH } \\
\text { ER \#1 }\end{array}$ & $\begin{array}{l}\text { DEPTH } \\
\text { ER \#2 }\end{array}$ \\
\hline $3 / 30 / 94$ & 1130 & $\star *$ & $* *$ & $*$ & 0.15 & 0.18 \\
\hline $4 / 4 / 94$ & 1305 & 11.2 & 54 & 52 & 0.15 & .18 \\
\hline $4 / 11 / 94$ & 1300 & 10.0 & 58 & 52 & 0.18 & 0 \\
\hline $4 / 22 / 94$ & 1350 & 10.6 & 64 & 54 & 0.18 & 0.1 \\
\hline $5 / 2 / 94$ & 1150 & 9.8 & 62 & 54 & 0.15 & 0.1 \\
\hline $5 / 9 / 94$ & 1320 & 10.0 & 60 & 52 & 0.22 & 0.2 \\
\hline $5 / 16 / 94$ & 1215 & 7.8 & 60 & 58 & 0.22 & 0.2 \\
\hline $5 / 23 / 94$ & 1430 & 11.0 & 62 & 52 & 0.15 & 0.1 \\
\hline $5 / 31 / 94$ & 1315 & 9.4 & 62 & 54 & 0.13 & 0.1 \\
\hline $6 / 5 / 94$ & 1415 & 9.8 & 66 & 58 & 0.11 & 0.1 \\
\hline $6 / 13 / 94$ & 1410 & 8.8 & 70 & 58 & 0.11 & 0.1 \\
\hline $6 / 20 / 94$ & $* *$ & $\star \star$ & $* *$ & * * & $* *$ & * \\
\hline
\end{tabular}

STATION \#6

DATE TIME DO-ppm TEMP-MAX TEMP-MIN WATER DEPTH WATER DEPTH SAMPLER \#1 SAMPLER \#2

$\begin{array}{rrrllll}3 / 30 / 94 & 1200 & * * & * * & * * & 0.09 & 0.11 \\ 4 / 4 / 94 & 1315 & 11.2 & 60 & 49 & 0.12 & 0.09 \\ 4 / 11 / 94 & 1255 & 10.8 & 60 & 50 & 0.12 & 0.08 \\ 4 / 22 / 94 & 1355 & 9.8 & 62 & 50 & 0.12 & 0.08 \\ 5 / 2 / 94 & 1145 & 10.2 & 62 & 54 & 0.11 & 0.11 \\ 5 / 9 / 94 & 1315 & 10.0 & 58 & 52 & 0.18 & 0.14 \\ 5 / 16 / 94 & 1210 & 11.4 & 58 & 52 & 0.18 & 0.14 \\ 5 / 23 / 94 & 1620 & 11.0 & 60 & 52 & 0.11 & 0.12 \\ 5 / 31 / 94 & 1310 & 12.0 & 62 & 52 & 0.11 & 0.11 \\ 6 / 5 / 94 & 1410 & 9.0 & 64 & 54 & 0.08 & 0.11 \\ 6 / 13 / 94 & 1405 & 11.2 & 68 & 54 & 0.08 & 0.11 \\ 6 / 20 / 94 & * * & * * & * * & * * & * * & * *\end{array}$


STATION \#7

DATE TIME DO-pPM TEMP-MAX TEMP-MIN WATER DEPTH WATER DEPTH

SAMPLER \#1 SAMPLER \#2

$\begin{array}{rrrllll}3 / 30 / 94 & 1215 & * * & * * & * * & 0.11 & 0.12 \\ 4 / 4 / 94 & 1225 & 10.0 & * * & * * & 0.11 & 0.12 \\ 4 / 11 / 94 & 1255 & 10.0 & 60 & 52 & 0.11 & 0.12 \\ 4 / 22 / 94 & 1355 & 9.7 & 60 & 52 & 0.11 & 0.12 \\ 5 / 2 / 94 & 1145 & 10.2 & 60 & 52 & 0.12 & 0.11 \\ 5 / 9 / 94 & 1440 & 9.8 & 60 & 52 & 0.13 & 0.13 \\ 5 / 16 / 94 & 1130 & 10.2 & 64 & 52 & 0.13 & 0.13 \\ 5 / 23 / 94 & 1650 & 11.2 & 60 & 52 & 0.09 & 0.09 \\ 5 / 31 / 94 & 1210 & 9.4 & 68 & 54 & 0.08 & 0.09 \\ 6 / 5 / 94 & 1335 & 10.0 & 68 & 58 & 0.08 & 0.08 \\ 6 / 13 / 94 & 1330 & 8.6 & 70 & 58 & 0.07 & 0.07 \\ 6 / 20 / 94 & * & * * & * * & * * & * * & *\end{array}$

STATION \#8

DATE TIME DO-ppM TEMP-MAX TEMP-MIN WATER DEPTH WATER DEPTH SAMPLER \#1 SAMPLER \#2

$\begin{array}{rrrllll}3 / 30 / 94 & 1055 & * * & * * & * * & 0.13 & 0.13 \\ 4 / 4 / 94 & 1150 & 9.2 & 61 & 58 & 0.11 & 0.09 \\ 4 / 11 / 94 & 1255 & 9.0 & 60 & 58 & 0.11 & 0.13 \\ 5 / 2 / 94 & 1145 & 9.8 & 68 & 59 & 0.11 & 0.11 \\ 5 / 9 / 94 & 1510 & 9.2 & 68 & 59 & 0.13 & 0.17 \\ 5 / 16 / 94 & 1100 & 8.4 & 68 & 59 & 0.13 & 0.17 \\ 5 / 23 / 94 & 1720 & 9.6 & 68 & 59 & 0.11 & 0.13 \\ 5 / 31 / 94 & 1140 & 9.0 & 66 & 60 & 0.11 & 0.11 \\ 6 / 5 / 94 & 1305 & 8.0 & 66 & 64 & 0.08 & 0.11 \\ 6 / 13 / 94 & 1300 & 8.0 & 74 & 62 & 0.07 & 0.07 \\ 6 / 20 / 94 & * * & * * & * * & * * & * * & *\end{array}$

** No data collected 
APPENDIX D

\section{WATER QUALITY DATA FOR SAN FRANCISQUITO CREEK 1994*}

\begin{tabular}{|c|c|c|c|c|c|c|c|c|}
\hline $\begin{array}{l}\text { LOCA- } \\
\text { TION }\end{array}$ & $\begin{array}{l}\text { DATE/ } \\
\text { TIME }\end{array}$ & $\mathrm{PH}$ & $\begin{array}{l}\text { TURBIDI } \\
\text { TY } \\
\text { (NTU) }\end{array}$ & $\begin{array}{l}\text { CONDU } \\
\text { CTIVITY } \\
\text { (UMHO/ } \\
\text { CM) }\end{array}$ & $\begin{array}{l}\mathrm{NO} 2 \text { as } \\
\text { NO2 } \\
\text { (ppm) }\end{array}$ & $\begin{array}{l}\mathrm{NO} 3 \text { as } \\
\text { NO3 } \\
\text { (ppm) }\end{array}$ & $\begin{array}{l}\mathrm{NH3} \text { as } \\
\mathrm{N} \text { (ppm) }\end{array}$ & $\begin{array}{l}\mathrm{PO} 4 \text { as } \mathrm{P} \\
(\mathrm{ppm})\end{array}$ \\
\hline 1 & $\begin{array}{l}4 / 4 / 94 \\
@ 1430\end{array}$ & 8.2 & 0.83 & 956 & $<0.05$ & 5.3 & $<0.1$ & $<0.05$ \\
\hline 2 & 1400 & 8.2 & 0.81 & 970 & $<0.05$ & 5.3 & $<0.1$ & $<0.05$ \\
\hline 3 & 1340 & 8.1 & 0.62 & 914 & $<0.05$ & 5.2 & $<0.1$ & $<0.05$ \\
\hline 4 & 1255 & 8.1 & 0.43 & 907 & $<0.05$ & 5.6 & $<0.1$ & $<0.05$ \\
\hline 5 & 1300 & 8.0 & 0.52 & 858 & $<0.05$ & 5.4 & $<0.1$ & $<0.05$ \\
\hline 6 & 1310 & 8.2 & 0.01 & 1337 & $<0.05$ & 4.8 & $<0.1$ & $<0.05$ \\
\hline 7 & 1225 & 8.2 & 0.81 & 758 & $<0.05$ & 2.0 & $<0.1$ & $<0.05$ \\
\hline 8 & 1150 & 8.1 & 0.31 & 702 & $<0.05$ & 2.2 & $<0.1$ & $<0.05$ \\
\hline 1 & $\begin{array}{l}4 / 17 / 94 \\
@ 1140\end{array}$ & 7.9 & 0.76 & 1049 & $<0.05$ & 5.1 & 0.1 & $<0.05$ \\
\hline 2 & 1145 & 7.9 & 0.80 & 994 & $<0.05$ & 5.0 & 0.2 & $<0.05$ \\
\hline 3 & 1150 & 7.8 & 0.85 & 960 & $<0.05$ & 5.2 & 0.2 & $<0.05$ \\
\hline 4 & 1200 & 7.8 & 0.82 & 972 & $<0.05$ & 5.2 & 0.2 & $<0.05$ \\
\hline 5 & 1205 & 7.8 & 1.03 & 903 & $<0.05$ & 5.2 & $<0.1$ & $<0.05$ \\
\hline 6 & 1212 & 8.4 & 0.18 & 1360 & $<0.05$ & 5.0 & $<0.1$ & $<0.05$ \\
\hline 7 & 1220 & 7.8 & 3.3 & 736 & $<0.05$ & 2.2 & $<0.1$ & $<0.05$ \\
\hline 8 & 1235 & 7.9 & 0.36 & 726 & $<0.05$ & 2.1 & $<0.1$ & $<0.05$ \\
\hline 1 & $\begin{array}{l}5 / 2 / 94 \\
@ 1025\end{array}$ & 7.8 & 0.72 & 982 & $<0.05$ & 4.9 & $<0.1$ & $<0.05$ \\
\hline 2 & 1050 & 7.8 & 0.62 & 940 & $<0.05$ & 4.6 & $<0.1$ & $<0.05$ \\
\hline 3 & 1105 & 7.7 & 0.54 & 886 & $<0.05$ & 5.0 & $<0.1$ & $<0.05$ \\
\hline 4 & 1135 & 7.7 & 0.58 & 888 & $<0.05$ & 5.2 & $<0.1$ & $<0.05$ \\
\hline 5 & 1150 & 7.7 & 0.62 & 839 & $<0.05$ & 5.0 & $<0.1$ & $<0.05$ \\
\hline 6 & 1145 & 7.9 & 0.70 & 1341 & $<0.05$ & 4.6 & $<0.1$ & $<0.05$ \\
\hline 7 & 1215 & 7.8 & 0.72 & 744 & $<0.05$ & 2.4 & $<0.1$ & $<0.05$ \\
\hline 8 & 1245 & 8.0 & 0.64 & 706 & $<0.05$ & 2.3 & $<0.1$ & $<0.05$ \\
\hline
\end{tabular}




\begin{tabular}{|c|c|c|c|c|c|c|c|c|}
\hline $\begin{array}{l}\text { LOCA- } \\
\text { TION }\end{array}$ & $\begin{array}{l}\text { DATE/ } \\
\text { TMEE }\end{array}$ & $\mathrm{PH}$ & $\begin{array}{l}\text { TURBDI } \\
\text { TY } \\
\text { (NTU) }\end{array}$ & $\begin{array}{l}\text { CONDU } \\
\text { CTIVITY } \\
\text { (UMHO/ } \\
\text { CM) }\end{array}$ & $\begin{array}{l}\text { NO2 as } \\
\text { NO2 } \\
\text { (ppm) }\end{array}$ & $\begin{array}{l}\text { NO3 as } \\
\text { NO3 } \\
\text { (ppm) }\end{array}$ & $\begin{array}{l}\mathrm{NH} 3 \text { as } \mathrm{N} \\
\text { (ppm) }\end{array}$ & $\begin{array}{l}\mathrm{PO} 4 \text { as } \mathrm{P} \\
(\mathrm{ppm})\end{array}$ \\
\hline 1 & $\begin{array}{l}5 / 16 / 94 \\
@ 1255\end{array}$ & 7.9 & 0.7 & 924 & $<0.05$ & 5.0 & $<, 0.1$ & 0.08 \\
\hline 2 & 1245 & 7.8 & 0.8 & 922 & $<0.05$ & 4.9 & 0.1 & 0.20 \\
\hline 3 & 1230 & 7.7 & 0.9 & 888 & $<0.05$ & 4.8 & 0.1 & 0.20 \\
\hline 4 & 1200 & 7.8 & 1.0 & 897 & $<0.05$ & 4.8 & 0.1 & 0.20 \\
\hline 5 & 1215 & 7.7 & 0.9 & 854 & $<0.05$ & 4.7 & 0.1 & 0.20 \\
\hline 6 & 1210 & 7.9 & 0.1 & 973 & $<0.05$ & 4.5 & $<0.1$ & 0.30 \\
\hline 7 & 1130 & 7.7 & 0.8 & 741 & $<0.05$ & 2.4 & 0.1 & 0.20 \\
\hline 8 & 1100 & 7.8 & 2.5 & 691 & $<0.05$ & 2.4 & 0.2 & 0.20 \\
\hline 1 & $\begin{array}{l}5 / 31 / 94 \\
@ 1355\end{array}$ & 8.0 & 0.94 & 968 & $<0.05$ & 5.0 & $<0.1$ & $<0.05$ \\
\hline 2 & 1350 & 8.1 & 1.02 & 950 & $<0.05$ & 5.1 & 0.2 & 0.08 \\
\hline 3 & 1330 & 8.1 & 1.12 & 980 & $<0.05$ & 4.9 & 0.1 & 0.08 \\
\hline 4 & 1235 & 8.0 & 0.88 & 920 & $<0.05$ & 4.8 & $<0.1$ & 0.08 \\
\hline 5 & 1315 & 7.9 & 0.92 & 890 & $<0.05$ & 4.8 & 0.2 & 0.08 \\
\hline 6 & 1310 & 8.0 & 1.02 & 940 & $<0.05$ & 9.0 & 0.3 & 0.08 \\
\hline 7 & 1210 & 7.8 & 1.08 & 820 & $<0.05$ & 5.1 & 0.2 & 0.08 \\
\hline 8 & 1140 & 8.0 & 0.86 & 742 & $<0.05$ & 5.0 & $<0.1$ & 0.08 \\
\hline 1 & $\begin{array}{l}6 / 13 / 94 \\
@ 1450\end{array}$ & 8.0 & 2.6 & 1342 & $<0.05$ & 5.4 & 0.37 & 0.22 \\
\hline 2 & 1440 & 8.0 & 1.8 & 1310 & $<0.05$ & 5.6 & 0.59 & 0.29 \\
\hline 3 & 1430 & 7.8 & 1.3 & 1154 & $<0.05$ & 5.6 & 0.30 & 0.21 \\
\hline 4 & 1400 & 8.1 & 1.4 & 1175 & $<0.05$ & 5.7 & 0.32 & 0.18 \\
\hline 5 & 1425 & 7.9 & 0.9 & 1122 & $<0.05$ & 5.6 & 0.34 & 0.19 \\
\hline 6 & 1409 & 8.3 & 0.4 & 1200 & $<0.05$ & 5.4 & 0.27 & 0.19 \\
\hline 7 & 1315 & 7.8 & 1.0 & 905 & $<0.05$ & 3.7 & 0.35 & 0.16 \\
\hline 8 & 1300 & 7.7 & 3.4 & 699 & $<0.05$ & 2.7 & 0.44 & 0.10 \\
\hline
\end{tabular}

*Samples collected by Douglas Herman and analyzed by Scientific Environmental Laboratories. 